\title{
Post-glacial Foraminifera of the incised Yangtze paleo-valley and paleoenvironmental implications
}

\author{
Xue Ke, ${ }^{1}$ Baohua Li, ${ }^{2 *}$ Zongyan Zhang, ${ }^{3}$ Yi Wei, ${ }^{4}$ Fei Hu, ${ }^{1}$ Dongwen Fan, ${ }^{1}$ Li Sun, ${ }^{1}$ Jianlei Xie, ${ }^{5}$ \\ Junjie $\mathrm{Yu}^{6}{ }^{6}$ and Huazhou $\mathrm{Yao}^{3}$ \\ ${ }^{1}$ Institute of Geological Survey, China University of Geosciences, Wuhan, 430074, Peoples Republic of China 〈xue_ke@cug.edu.cn〉,

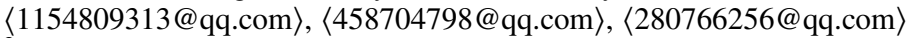 \\ ${ }^{2}$ Nanjing Institute of Geology and Palaeontology, Chinese Academy of Sciences, Nanjing, 210008, Peoples Republic of China 〈bh-li@nigpas.ac.cn〉 \\ ${ }^{3}$ Wuhan Center, China Geological Survey, Wuhan 430223, Peoples Republic of China 〈conodonts@163.com〉〈Ycxc2009@126.com〉 \\ ${ }^{4}$ Safety Engineering College, North China Institute of Science \& Technology, Langfang 065210, Peoples Republic of China 〈weiy712@ gmail.com〉 \\ ${ }^{5}$ Geological environment research, Shanghai Institute of Geological Survey, Shanghai 200072, Peoples Republic of China 〈45118880@qq.com〉 \\ ${ }^{6}$ Nanjing Center, China Geological Survey, Nanjing 210016, Peoples Republic of China 〈25320701@qq.com〉
}

\begin{abstract}
Three gravity cores (LZK1, ZKA4, and CSJA6) from the incised Yangtze paleo-valley comprise a thick sequence of the post-glacial deposit. Nineteen genera (26 species) of the benthic foraminifers are described from these cores, with detailed down-core foraminiferal variations to investigate their paleoenvironmental implications. Three foraminiferal assemblages are recognized for the lower, middle, and upper parts of the cores respectively. The lower part is dominated by Ammonia beccarii var. and Florilus decorus with lower abundance and diversity. In the middle part, the foraminifers are abundant and diverse, dominated by both Ammonia beccarii var. and Elphidium advenum. Cavarotalia annectens, Pararotalia nipponica, and porcellaneous benthic foraminiferal forms are always present, sometimes abundant. The upper part is characterized by the Ammonia beccarii-Elphidium magellanicum assemblage, except for the Core ZKA4, which is barren of foraminifers in this interval. AMS ${ }^{14} \mathrm{C}$ dates and foraminiferal assemblages both confirm that the transgression-regression sequence in these cores belongs to the "Ammonia transgression" during the Holocene. In addition to documenting the post-glacial sea-level fluctuations, the benthic foraminifers also reflect a warmer climate during the early-middle Holocene. The foraminiferal differences among the three cores can be used to interpret the influence of seawater during the post-glacial sea-level fluctuations. The area in the vicinity of Core ZKA4 was affected by marine water only during the middle Holocene, which was much shorter than the areas of the other cores.
\end{abstract}

\section{Introduction}

Sediments of the coastal plains and the continental shelves record the dynamic history of the shoreline migration caused by the $\sim 120 \mathrm{~m}$ sea-level changes during the Quaternary (Fleming et al., 1998). Through regional micropaleontological and stratigraphic comparisons in the sedimentary cores from East China, four major marine transgressions have been recognized during the late Pleistocene. The last one, post-glacial "Ammonia transgression", is the most notable and widespread along the coastline (Wang et al., 1981). Numerous boreholes have been drilled and studied in various parts of East China over the last several decades (Lin, 1979; Wang and Min, 1979; Li et al., 1988; Zhu and Lin, 1990; Chen and Stanley, 1995; Stanley and Chen, 1996; Wang et al., 2002; Shu et al., 2010; Xiong et al., 2010; Wang et al., 2012). However, introduction of old carbon and reworking resulted in less-reliable dates, which has hampered further study on the glacial-interglacial environmental changes in East China (Stanley and Chen, 2000).

* Corresponding author
Due to the lower last glacial sea level and excavation of previous marine sediments, the deeply incised Yangtze paleovalley received a significant amount of post-glacial deposits, up to $80 \mathrm{~m}$ thick in this region ( $\mathrm{Li}$ and Wang, 1998; Li et al., 2000), which provides an excellent opportunity for reconstructing the post-glacial environmental changes in East China.

In this study, benthic foraminiferal assemblages are reported from three cores of the incised Yangtze paleo-valley. The foraminiferal fauna can be correlated with records of previous studies in the Yangtze Delta region. Based on reliable AMS ${ }^{14} \mathrm{C}$ dates, the high-resolution foraminiferal data presented here provide new evidence for post-glacial variations in climate and depositional environments.

\section{Geological setting}

The Yangtze Delta has been developing in a sedimentary basin formed in association with the Quaternary neotectonic orogeny in East China (Guo et al., 1997; Wang et al., 2008). The Quaternary stratigraphic sequence of the Yangtze Delta is up to 


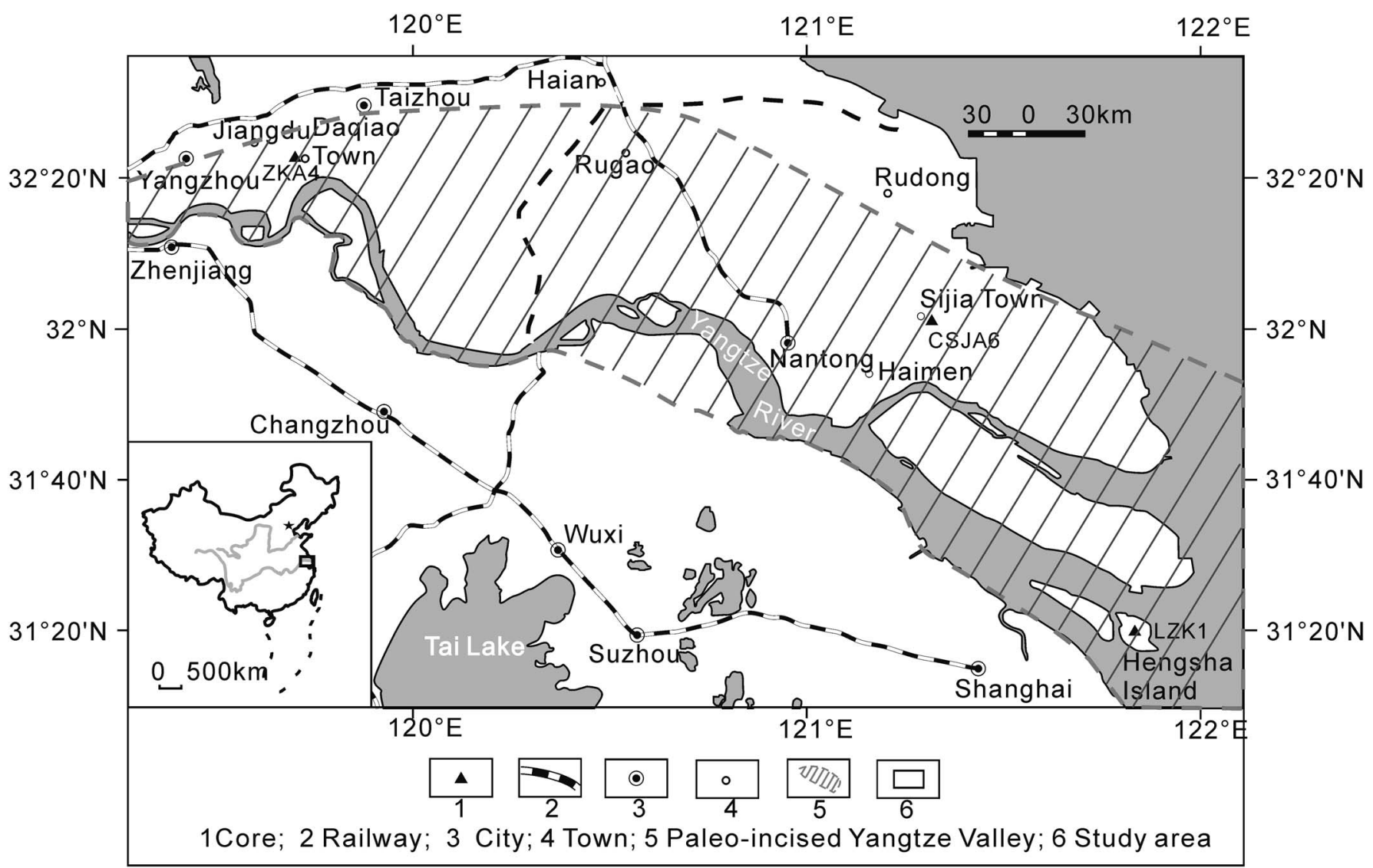

Figure 1. Location map showing the cores studied in the paleo-incised Yangtze Valley (range of paleo-incised Yangtze Valley after Li et al., 2000).

$300 \mathrm{~m}$ thick, consisting of the Haimen Formation (lower Pleistocene), Qidong Formation (Middle Pleistocene), Kunshan Formation (MIS 5), Gehu Formation (MIS 3), and Rudong Formation (Holocene) (Wu and $\mathrm{Li}, 1987$ ). The Rudong Formation is represented by fluvial, estuary, shallow marine, and deltaic facies, and can be divided into three members: the lower member is composed of gray silt and grayish black slit clay; the middle is composed of gray or grayish black silt, fine-grained sand, and slit clay; and the upper member is composed of grayish yellow clay, clayey silt, and gray silt ( $\mathrm{Wu}$ and $\mathrm{Li}, 1987)$.

The Yangtze Delta can be subdivided into three units: the incised paleo-valley and the northern and southern flanks (Fig. 1; Li et al., 2000). The incised paleo-valley is an area where the estuary migrated, which contains several subdeltas and estuary bars. With rising sea level, the post-glacial marine transgression resulted in filling the incised valley and formation of the river channel, floodplain-estuary, estuarine-shallow marine, and deltaic sedimentary facies (Li et al., 2000). Since the middle Holocene, the delta has been developing mainly in the incised valley, prograding to the east and southeast (Li et al., 2002; Wang et al., 2013).

\section{Materials and methods}

The upper $42.2 \mathrm{~m}, 86 \mathrm{~m}$, and $67 \mathrm{~m}$ of deposits in cores ZKA4, LZK1, and CSJA6, respectively, comprise the Rudong Formation. The sedimentary sequence varies from gravelly sand, coarse-grained sand in the basal part, fining-upward to the main part of gray, grayish yellow, brown, or slate gray silt, silty clay, and clayey silt. Planar bedding, lenticular bedding, and microerosional surfaces are locally present (Fig. 2).

We analyzed 455 samples that were collected from the three cores at $10-50 \mathrm{~cm}$ intervals. All samples were air-dried and weighed, and soaked in water for one week. Diluted $\mathrm{H}_{2} \mathrm{O}_{2}$ (5\%) was added to help disaggregate the indurated samples when needed. After the samples were washed through a $74 \mu \mathrm{m}$ sieve, the coarse fraction was oven dried at $60^{\circ} \mathrm{C}$ and stored for foraminiferal studies. All the foraminiferal specimens were picked, identified, and counted. The Shannon index (Hs) was calculated to evaluate the variation of benthic foraminiferal complex diversity (Shannon, 1948).

AMS ${ }^{14} \mathrm{C}$ dating of Core ZKA4 and Core CSJA6 was performed on the plant debris, charcoal, or the whole sediments either at Beta Analytic Inc. or Peking University (Yu et al., 2014; Ma et al., 2015; Table 1).

Repositories and institutional abbreviations.-All cores examined in this study are from the paleo-valley of the Yangtze Delta, including one core from Shanghai (LZK1) and the other two from Jiangsu Province (ZKA4 and CSJA6; Fig. 1). Core LZK1 $\left(31^{\circ} 20^{\prime} \mathrm{N}, 121^{\circ} 50^{\prime} \mathrm{E}\right)$ is just $0.25 \mathrm{~m}$ above the China National Vertical Datum (CNVD, 1985); cores ZKA4 (32 $\left.22^{\circ} \mathrm{N}, 119^{\circ} 37^{\prime} \mathrm{E}\right)$ and CSJA6 $\left(32^{\circ} 05^{\prime} \mathrm{N}, 121^{\circ} 17^{\prime} \mathrm{E}\right)$ are $6 \mathrm{~m}$ and $4 \mathrm{~m}$ above the CNVD, respectively. All described specimens are housed at the Nanjing Institute of Geology and Palaeontology (NIGP), Chinese Academy of Science. Referred type specimens are 


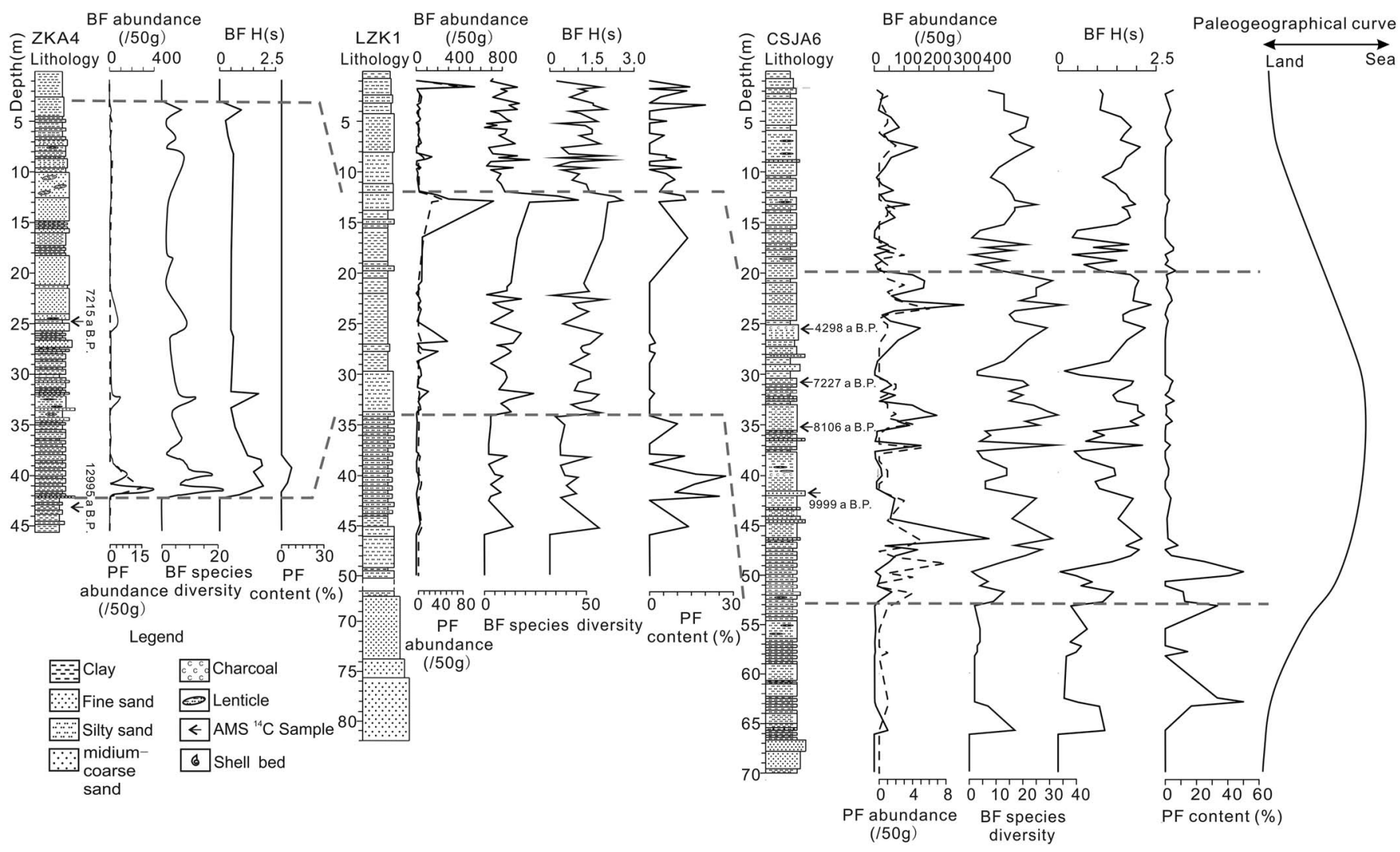

Figure 2. Variation of Lithology, benthic foraminiferal abundance, diversity, and H(s), planktonic foraminiferal content in the cores ZKA4, LZK1, and CSJA6, with reconstructed paleogeographic curve. Solid line represents BF abundance $(/ 50 \mathrm{~g})$; dashed line represents PF abundance $(/ 50 \mathrm{~g})$.

Table 1. AMS ${ }^{14} \mathrm{C}$ dates of Core ZKA4 and CSJA6 (Yu et al., 2014; Ma et al., 2015).

\begin{tabular}{lcclcc}
\hline Laboratory No. & Core & Core depth $(\mathrm{m})$ & Material & $\begin{array}{c}\text { Conventional Age } \\
(\mathrm{Myr})\end{array}$ & $\begin{array}{c}\text { Cal Age } \\
(2 \sigma, \mathrm{Myr})\end{array}$ \\
\hline Beta-311252 & ZKA4 & $24.8-24.9$ & plant debris & $6280 \pm 40$ & $7160-7270$ \\
Beta-311253 & ZKA4 & $43.15-43.30$ & organic sedimen & $11110 \pm 50$ & $12880-13110$ \\
BA120993 & CSJA6 & 25.5 & plant debris & $3865 \pm 30$ & $4159-4412$ \\
BA120995 & CSJA6 & $30.7-30.8$ & silty clay & $6305 \pm 50$ & $7169-7272$ \\
BA120997 & CSJA6 & 35.1 & plant debris & $7305 \pm 30$ & $8030-8176$ \\
BA120999 & CSJA6 & 41.7 & charcoal & $8855 \pm 35$ & $9777-10157$ \\
\hline
\end{tabular}

housed at the National Museum of Natural History, Smithsonian Institution, Washington, D.C. (USNM), CC = Cushman collection; $\mathrm{MO}=$ mollusk collection; The Natural History Museum, London $(\mathrm{BMNH}), \mathrm{HA}=$ Heron-Allen slide collection, $\mathrm{ZF}=$ Zoology: Foraminifera; Geological Museum, Louisiana State University, Baton Rouge, Louisiana (LSUGM); and Tongji University, Shanghai (TJU), $\mathrm{H}=$ Hai (Marine in phonetics Chinese).

\section{Systematic paleontology}

The classification of the order Foraminiferida follows that given by He et al. (1965), Wang et al. (1988), and Loeblich and Tappen (1988).

Order Foraminiferida Eichwald, 1830

Suborder Miliolina Delage and Hérouard, 1896

Family Miliolidae Ehrenberg, 1839

Genus Quinqueloculina d'Orbigny, 1826
Quinqueloculina lamarckiana d'Orbigny, 1839a Figure 3.1-3.3

1839a Quinqueloculina lamackiana d'Orbigny, p. 189, pl. 11, figs. 14, 15.

1884 Quinqueloculina cuvieriana; Brady, p. 162, pl. 5, figs. 1-3.

1929 Quinqueloculina lamarckiana; Cushman, p. 26, pl. 2, figs. 6a-6c.

1965 Quinqueloculina lamarckiana; $\mathrm{He}, \mathrm{Hu}$, and Wang, p. 61, pl. 2, figs. 1a-1c.

1965 Quinqueloculina lamarckiana minuscule $\mathrm{Ho}, \mathrm{Hu}$, and Wang; $\mathrm{He}, \mathrm{Hu}$, and Wang, p. 61, pl. 2, figs. 2a-2c.

1988 Quinqueloculina lamarckiana; Wang et al., p. 127, pl. 13, figs. 10-12.

Occurrence.-Widely distributed in the world oceans; Recent coastal water and Quaternary sediments of Bohai Sea, Yellow 


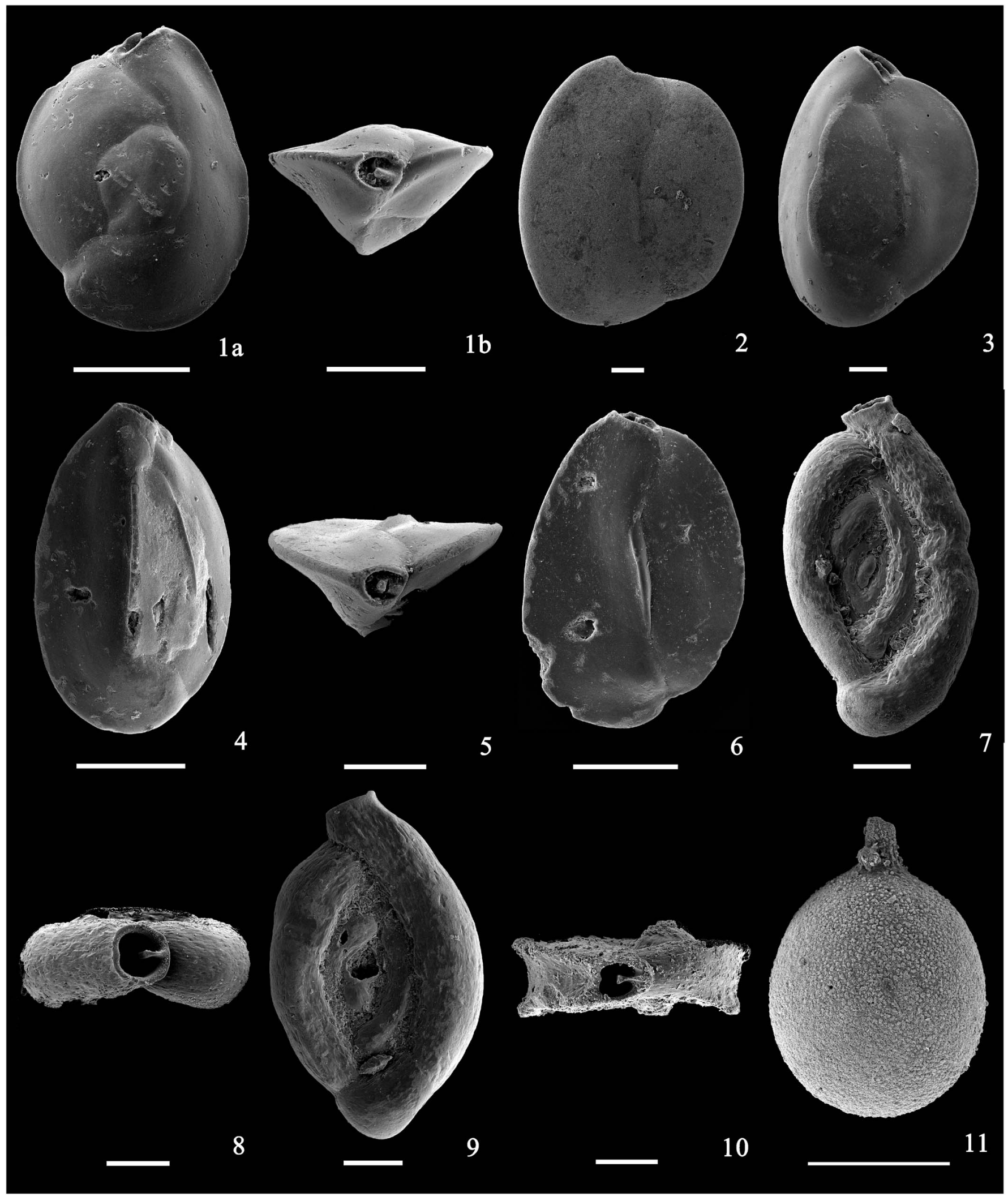

Figure 3. SEM photos of the foraminifers from Core CSJA6, Nantong, Jiangsu and Core LZK1, Hengsha Island, Shanghai. All scale bars are $100 \mu \mathrm{m}$. (1-3) Quinqueloculina lamarckiana: (1a) front view, CSJA6, depth 33.8-33.9 m, Reg. No. K2-036; (1b) apertural view, CSJA6, depth 33.8-33.9 m, Reg. No. K2-036; (2) rear view, LZK1, depth 31.9-32.0 m, Reg. No. K2-033; (3) front view, LZK1, depth 31.5-31.6 m, Reg. No. K2-032. (4-6) Quinqueloculina venusta: (4) front view, CSJA6, depth 33.8-33.9 m, Reg. No. K3-004; (5) apertural view, CSJA6, depth 47.6-47.7 m, Reg. No. K3-006 (6) rear view, CSJA6, depth 33.8-33.9 m, Reg. No. K3-005. (7, 8) Spiroloculina exmia: (7) side view, CSJA6, depth 47.6-47.7 m, Reg. No. K3-020; (8) apertural view, CSJA6, depth 47.6-47.7 m, Reg. No. K3-016. (9, 10) Spiroloculina jucunda: (9) side view, CSJA6, depth 34.2-34.3 m, Reg. No. K3-021; (10) apertural view, CSJA6, depth 33.8-33.9 m, Reg. No. K3-022. (11) Lagena hispida, side view, CSJA6, depth 17.2-17.3 m, Reg. No. K2-007. 
Sea, East China Sea, and South China Sea (Wang et al., 1988); Pliocene in Taiwan, China (He et al., 1965); Tropical Pacific (11-174 m; Jones, 1994).

Remarks. - This species was recognized by the broad elliptic shape and the sharply keeled periphery of the test. In this study, a wide variety was observed from nearly $0.1 \mathrm{~mm}$ (Fig. 3.1a, $3.1 \mathrm{~b}$ ) to $1 \mathrm{~mm}$ (Fig. 3.2, 3.3). The third chambers of the front view in the adult forms usually elevated as a keel, while juvenile forms have the convex, round ridge for this chamber. He et al. (1965) erected the smaller specimens to a new subspecies, which is considered here as a juvenile form of Quinqueloculina lamarckiana d'Orbigny (1839a). Cushman (1929) pointed that the species has an elliptical neck with a narrow elongate tooth. He (1965) reported a bifurcate top of the tooth. The specimens observed in this study have a narrow elongate tooth with or without a much shorter neck.

\section{Quinqueloculina venusta Karrer, 1868}

Figure 3.4-3.6

1868 Quinqueloculina venusta Karrer, p. 147, pl. 2, fig. 6.

1917 Quinqueloculina venusta; Cushman, p. 45, pl. 11, fig. 1.

1957 Quinqueloculina lamarckiana; Todd and Bronnimann, p. 27, pl. 3, fig. 12 .

1965 Quinqueloculina venusta; $\mathrm{He}, \mathrm{Hu}$, and Wang, p. 60, pl. 2, figs. 5a-5c.

1990 Quinqueloculina venusta; Ujiié, p, 15, pl. 3, figs. 3a, 3b, $4 \mathrm{a}, 4 \mathrm{~b}$.

Occurrence.-Pliocene in Japan; Miocene in Romania and Yugoslavia; Recent in Pacific and Atlantic oceans; Jiangsu and Shanghai, China (He et al., 1965).

Remarks.-Cushman (1917) reported that this species has a short contracted neck with thickened lip and a short simple tooth. He et al. (1965) presented specimens with slightly bifurcate top of the tooth. In this study, no definite lip can be observed. Due to its elongated test and wide short tooth, the specimens of Quinqueloculina lamarckiana d'Orbigny (1839a) described by Todd and Bronnimann (1957) are referred to Quinqueloculina venusta Karrer (1868).

Genus Spiroloculina d'Orbigny, 1826
Spiroloculina exmia Cushman, 1922 a

Figure 3.7, 3.8

1922a Spiroloculina exmia Cushman, p. 61, pl. 11, fig. 2.

1929 Spiroloculina exmia; Cushman, p. 42, pl. 8, figs. 7a, 7b. 1965 Spiroloculina exmia; He, Hu, and Wang, p. 72, pl. 4, figs. 5a, 5b.

Occurrence.-Recent tropical Pacific; Jiangsu, China (He et al., 1965).

Remarks.-This species possesses rapidly increased and tapered chambers toward the apertural end. He et al. (1965) reported that the early chambers are inclined and convex. The specimens reported here have a comparatively shorter neck.
Spiroloculina laevigata Cushman and Todd, 1944

Figure 4.1, 4.2

1944 Spiroloculina laevigata Cushman and Todd, p. 67, pl. 9, figs. 26-29.

1965 Spiroloculina laevigata; $\mathrm{He}, \mathrm{Hu}$, and Wang, p. 72, pl. 4, figs. 7a, 7b.

1988 Spiroloculina laevigata; Wang et al., p. 126, pl. 12, fig. 17.

Holotype-(USNM CC 41730 ) in National Museum of Natural History, Smithsonian Institution, Washington, D.C.

Occurrence.-Recent Pacific; Jiangsu, China (He et al., 1965).

Remarks.-This species is close to Spiroloculina exmia Cushman (1922a). Compared with the latter, the test of this species is more symmetric, and the chambers keep the same width from the base to the apertural end. The specimens illustrated here are more elongate than the holotype.

Suborder Lagenina Lankester, 1885

Family Nodosariidae Ehrenberg, 1838

Genus Lagena Walker and Jacob, 1798

Lagena hispida Reuss, 1858

Figure 3.11

1858 Lagena hispida Reuss, p. 434.

1884 Lagena hispida; Brady, p. 450, pl. 57, figs. 1-4.

1965 Lagena hispida; He, Hu, and Wang, p. 77, pl. 5, fig. 12.

1988 Lagena hispida; Wang et al., p. 135, pl. 16, fig. 12.

1990 Lagena hispida; Ujiié, p, 18, pl. 5, fig. 2.

Occurrence.-Oligocene in Germany; Quaternary in Denmark; Pliocene in U.S.A. and Japan; Recent in Pacific and Atlantic oceans; Yellow Sea and shelf of East China Sea (Wang et al., 1988).

Remarks. - The wall of this species is ornamented with fine spines. According to Brady (1884), the test varies from flaskshaped to subglobular, and in some specimens, the basal end is drawn out into a stout spine, which was also reported by Ujiié (1990). The stout spine out of the base was described, but not observed in the plates illustrated by $\mathrm{He}$ et al. (1965). The specimens here and reported by Wang et al. (1988) showed no spine for the subglobular test.

Lagena spicata Cushman and McCulloch, 1950

Figure 4.3, 4.4

1950 Lagena sulcata var. spicata Cushman and McCulloch, p. 360, pl. 48, figs. 3-7.

1965 Lagena striata; He, Hu, and Wang, p. 76, pl. 5, fig. 11. 1988 Lagena spicata; Wang et al., p. 135, pl. 16, figs. 9, 10.

Occurrence.-Widely distributed in world oceans; seldom found in shelf sediments of East China Sea (Wang et al., 1988).

Remarks.-There is a considerable amount of variation in this species. Cushman and McCulloch (1950) erected this species 


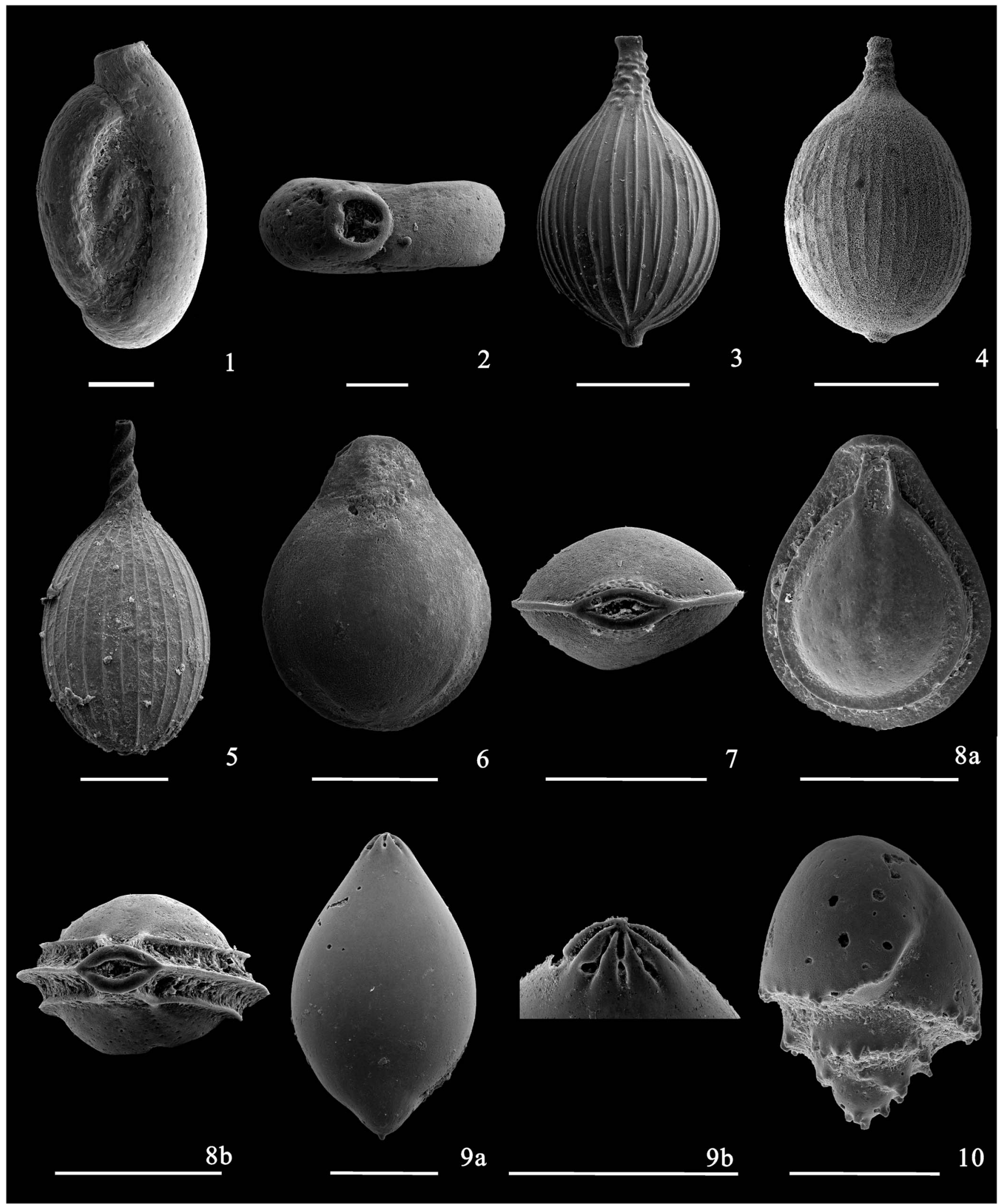

Figure 4. SEM photos of the foraminifers from Core CSJA6, Nantong, Jiangsu and Core LZK1, Hengsha Island, Shanghai. All scale bars are $100 \mu \mathrm{m}$. $(\mathbf{1}, 2)$ Spiroloculina laevigata: (1) side view, CSJA6, depth 47.6-47.7 m, Reg. No. K3-018; (2) apertural view, CSJA6, depth 47.6-47.7 m, Reg. No. K3-019. $(\mathbf{3}, 4)$ Lagena spicata: (3) side view, CSJA6, depth 20.8-20.9 m, Reg. No. K2-005; (4) side view, CSJA6, depth 13.8-13.9 m, Reg. No. K2-003. (5) Lagena substriata: side view, LZK1, depth 9.5-9.6 m, Reg. No. K2-008. (6, 7) Fissurina laevigata: (6) side view, LZK1, depth 12.3-12.4 m, Reg. No. K1-080; (7) apertural view, CSJA6, depth 23.2-23.3 m, Reg. No. K1-079. (8a, 8b) Fissurina orbignyana: (8a) side view, CSJA6, depth 7.5-7.6 m, Reg. No. K1-083; (8b) apertural view, CSJA6, depth 23.2-23.3 m, Reg. No. K1-083. (9a, 9b) Globulina minuta: (9a) side view, LZK1, depth 12.3-12.4 m, Reg. No. K1-087; (9b) apertural view, LZK1, depth 12.3-12.4 m, Reg. No. K1-087. (10) Bulmina marginata, side view, CSJA6, depth 31.2-31.3 m, Reg. No. K4-010. 
from Lagena sulcata in having the basal end drawn out into a stout spine while the latter has coarse longitudinal costae, extending to the base and forming numerous spines. The specimens reported here and by Wang et al (1988) have stronger stout spines than those from He et al. (1965). Circular costae can be observed on the neck of specimens in this study and in those of Wang et al (1988). The specimens in this study vary from flask-shaped to pyriform.

\section{Lagena substriata Williamson, 1858}

Figure 4.5

1858 Lagena vulgaris var. substriata Williamson, p. 7, pl. 1, fig. 14.

1913 Lagena striata var. substriata; Cushman, p. 20, pl. 8, figs. 1-3.

1923 Lagena substriata; Cushman, p. 56, pl. 10, fig.11.

1965 Lagena substriata; $\mathrm{He}, \mathrm{Hu}$, and Wang, p. 77, pl. 5, figs. 7,8 .

1988 Lagena substriata; Wang et al., p. 134, pl. 16, fig. 17. 1990 Lagena substriata; Ujiié, p. 19, pl. 5, fig. 7.

Occurrence.-Widely distributed in coastal water of the world oceans; inner and middle shelf of East China Sea (Wang et al., 1988).

Remarks. - This species is characterized by the costulate surface extending up on to the neck, often to its end, and usually spirally arranged on the neck (Cushman, 1913). He (1965) and Ujiié (1990) reported specimens similar to those illustrated here. The test is elongate compared with Lagena spicata Cushman and McCulloch (1950).

Family Polymorphinidae d'Orbigny, 1839a

Genus Fissurina Reuss, 1850

Fissurina laevigata Reuss, 1850

Figure 4.6, 4.7

1850 Fissurina laevigata Reuss, p. 366, pl. 46, fig. 1.

1965 Fissurina laevigata; He, Hu, and Wang, p. 79, pl. 5, fig. 14.

1988 Fissurina laevigata; Wang et al., p. 144, pl. 19, fig. 13.

1990 Fissurina sp.; Ujiié, p. 23, pl. 7, fig. 13.

1990 Fissurina periperforata; Ujiié, p. 25, pl. 8, fig. 10.

Occurrence.-Widely distributed in coastal water of the world oceans; shelf of East China Sea (Wang et al., 1988); 4-5715 m (Jones, 1994).

Remarks. - The species has a compressed chamber with singlekeel periphery. The Fissurina laevigata specimen illustrated by Ujiié (1990) is different from the present species by lacking the distinct peripheral keel and having a smaller aperture. Fissurina sp. and Fissurina periperforata Ujiié (1990) are similar to the present species, although Fissurina periperforata Ujiié (1990) has a more elongate form.

Fissurina orbignyana Seguenza, 1862

Figure 4.8a, 4.8b
1862 Fissurina orbignyana Seguenza, p. 66, pl. 2, figs. 25, 26.

1971 Fissurina orbignyana; Murray, p. 99, pl., 40, figs. 1-5.

1988 Fissurina orbignyana; Wang et al., p. 144, pl. 19, figs. 6,7 .

Occurrence.-Widely distributed in coastal water of the world oceans; Recent Pacific, Atlantic, and Gulf of Mexico; shelf of East China Sea (Wang et al., 1988).

Remarks.-This species is distinguished by its three-keel periphery and the most-prominent central one.

Genus Globulina d'Orbigny, 1839a

Globulina minuta (Roemer, 1838)

Figure 4.9a, 4.9b

1838 Polymorphina minuta Roemer, p. 386, pl. 3, fig. 35.

1863 Polymorphina sororia Reuss, p. 71, fig. 16.

1930 Globulina minuta; Cushman and Ozawa, p. 83, pl. 20, figs. 3, 4 .

1965 Globulina minuta; He, Hu, and Wang, p. 81, pl. 5, fig. 19.

Occurrence.-Early Pleistocene in Italy; inner shelf of East China Sea (Wang et al., 1988).

Remarks.-This species is distinguished by the fusiform test and fewer chambers. The last chamber is much bigger than others. Polymorhina sororia Reuss (1863) was considered a junior synonym of Globulina minuta (Roemer, 1838) by Cushman and Ozawa (1930). The specimen reported here is comparatively acute for both the basal and apertural ends, with a tiny acicular spine developed in the basal end.

Suborder Rotaliina Delage and Hérouard, 1896

Superfamily Buliminacea Jones in Griffith and Henfrey, 1875

Family Buliminidae Jones in Griffith and Henfrey, 1875 Genus Bulimina d'Orbigny, 1826

Bulimina marginata d'Orbigny, 1826

Figure 4.10

1826 Bulimina marginata d'Orbigny, p. 269, pl. 12, figs. 10-12.

1922b Bulimina marginata; Cushman, p. 91, pl. 21, figs. 4, 5.

1965 Bulimina marginata; $\mathrm{He}, \mathrm{Hu}$, and Wang, p. 84, pl. 6, fig. 7.

1965 Bulimina marginospinata ovata; He, Hu, and Wang, p. 85 pl. 6 , fig. 8 .

1988 Bulimina marginata; Wang et al., p. 144, pl. 21, fig. 6, pl. 34, figs. 11-15.

Occurrence.-Widely distributed in coastal water of the world oceans; inner and middle shelf of East China Sea (Wang et al., 1988).

Remarks.-This species has a great number of varieties for the juvenile and adult forms. Wang et al. (1988) conducted a morphometric analysis of 200 tests from the surface sediments of the East China Sea, and displayed a concentrated and continuous distribution for tests of different length and breadth, 
which suggests that these short oval or/and high fusiform forms belong to the same species. The specimen illustrated here has a shorter test, resembling the juvenile form of Bulimina marginata d'Orbigny (1826). The rim of the early chambers has a series of short blunt spines, while the later chamber has a series of crenulations.

Family Bolivinitidae Cushman, 1927

Genus Bolivina d'Orbigny, 1839b

Bolivina robusta Brady, 1881

Figure 5.1, 5.2

1881 Bolivina robusta Brady, p. 57.

1922b Bolivina robusta var.; Cushman, p. 46, pl. 6, fig. 6.

1965 Bolivina robusta; $\mathrm{He}, \mathrm{Hu}$, and Wang, p. 87, pl. 6, fig. 13.

1965 Bolivina cochei; $\mathrm{He}, \mathrm{Hu}$, and Wang, p. 88, pl. 6, figs. 16, 17.

1965 Bolivina obscura; $\mathrm{He}, \mathrm{Hu}$, and Wang, p. 88, pl. 7, figs. 1-3.

1988 Bolivina robusta; Wang et al., p. 147, pl. 34, figs. 1-5. 1994 Bolivina robusta; Jones, pl. 53, figs. 7-9.

Holotype.-Syntype (BMNH ZF1194) from Challenger Sta. 191A, Kai Island, Central Pacific (1061 m); (BMNH ZF1195) from Challenger Sta. 174B, Fiji, Pacific (2041 m).

Occurrence.-Recent coastal water and Quaternary sediments of Bohai Sea, Yellow Sea, East China Sea and South China Sea (Wang et al., 1988); 13-3475 m (Jones, 1994).

Remarks.-This species has great variability in morphology. Wang et al (1988) reported the megalospheric and microspheric tests. The specimens illustrated here are elongated cuneiform with blunt basal end, resembling a microspheric test. It was also reported that a long sharp spine may exist for this species (Jones, 1994, p. 58, pl. 53, figs. 8, 9).

\section{Superfamily Discorbacea Ehrenberg, 1838 \\ Family Discorbidae Ehrenberg, 1838 \\ Genus Rosalina d'Orbigny, 1826 \\ Rosalina bradyi (Cushman, 1915)}

Figure 5.7-5.9

1915 Discobis globularis var. bradyi Cushman, p. 12, pl. 8, fig. 1.

1931 Discorbis globularis; Cushman, p. 22, pl. 4, figs. 9a-9c.

1960 Rosalina bradyi; Barker, pl. 86, fig. 8.

1965 Rosalina bradyi; He, Hu, and Wang, p. 89, pl. 8, figs. 5a-5c, 6a-6c.

1988 Rosalina bradyi; Wang et al., p. 156, pl. 23, fig. 12.

Holotype.-USNM 9027 from Alabatross station D4863 in 194 m off Japan (Cushman, 1915, pl. 8, fig. 1).

Occurrence.--Neogene to Recent in Japan; Recent Pacific; East China Sea, South China Sea; inner shelf in East China Sea (He et al., 1965; Wang et al., 1988).

Remarks.-The test of this species is compressed. The specimens illustrated here clearly show the wall difference between the coarse-perforated dorsal and fine-perforated ventral sides (Figure 5.8). The umbilical lobe of specimens is scattered and thickened.

\section{Genus Buccella Andersen, 1952 \\ Buccella frigida (Cushman, 1922c) \\ Figure 5.10-5.12}

1922c Pulvinulina frigida Cushman, p. 144.

1931 Eponides frigida; Cushman, p. 45.

1952 Bucella frigida; Anderson, p. 144, figs. 4-6.

1965 Buccella frigida; $\mathrm{He}, \mathrm{Hu}$, and Wang, p. 93, pl. 8, figs. $4 \mathrm{a}-4 \mathrm{c}$.

1988 Buccella frigida; Wang et al., p. 157, pl. 23, figs. 3, 4.

Holotype.-Lectotype (USNM CC 3032) from station 5, bay between Black Whale and Olasks Harbors, east coast of Hudson Bay at $18 \mathrm{~m}$ water depth (Cushman, 1931).

Occurrence.-Recent Arctic, Okhotsk Sea, Japan Sea, Bering Sea, Pacific, northern Atlantic; Bohai Sea, Yellow Sea, northwest of East China Sea, and the South China Sea; Quaternary in Jiangsu Province (He et al.,1965, Wang et al., 1988); 34-402 m (Jones, 1994).

Remarks. - The dorsal side of this species is filled with an amorphous material radiating out from the umbilical region. These materials usually distribute along the sutures. Less amorphous material may be observed for the later sutures. Supplementary apertures lie at the ends of the sutures, forming bigger pores and usually covered by the same amorphous material (Fig. 5.11). The amorphous material may be more around the supplementary aperture than the central umbilicus area. A slightly keeled periphery was also observed (NHM ZF 2220-2221). However, the keel is indistinct in the specimens of this study.

\author{
Genus Helenina Saunders, 1961 \\ Helenina anderseni (Warren, 1957)
}

Figure 6.4-6.6

1957 Pseudoeponides anderseni Warren, p. 39, pl. 4, figs. 12-15.

1957 Helenina anderseni; Saunders, p. 374.

1961 Helenina anderseni; Saunders, p. 148.

1988 Helenina anderseni; Wang et al., p. 158, pl. 24, figs. 1, 2.

2011 Helenina anderseni; Gennari et al., p. 249, pl. 1, figs. $1-6$, pl. 2, figs. 1-4.

Holotype.-(LSUGM 2009) from wet marsh on the northeast side of Crosscut Canal at Bay Pomme d'Or (Warren, 1957, pl. 4, fig. 12-15).

Occurrence.-Widely distributed in low-salinity coastal water; inner shelf of East China Sea (Wang et al., 1988).

Remarks._Warren (1957) erected this species, which usually has supplementary apertures within the deeply incised sutures dorsally near the junction of spiral and septal sutures, and within the incised sutures ventrally near their middle points. 


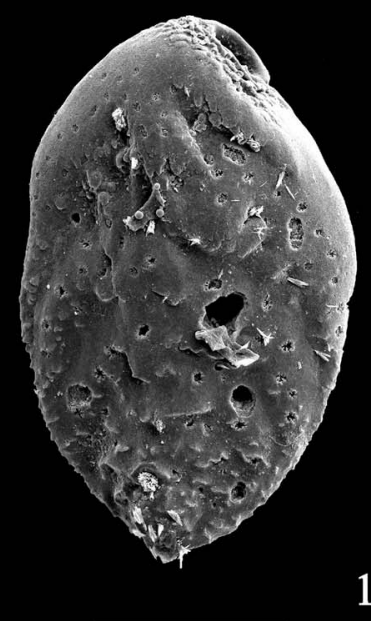

1

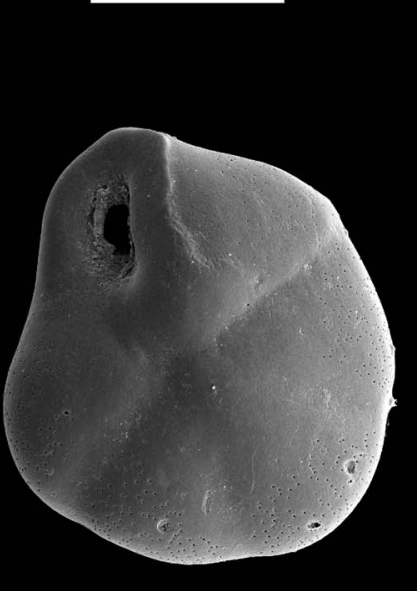

5
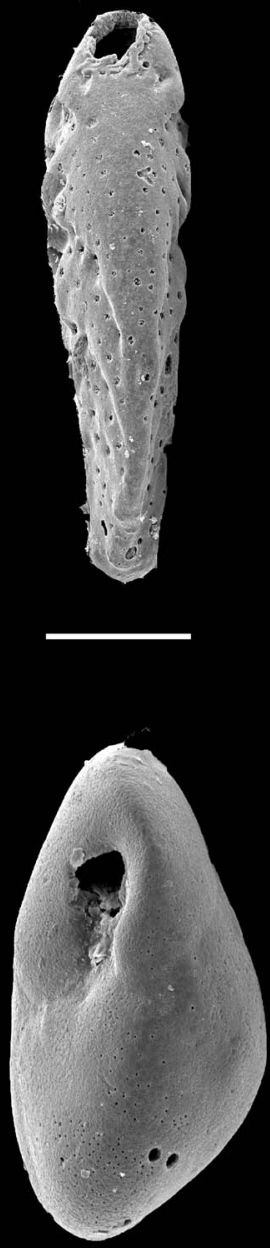

6

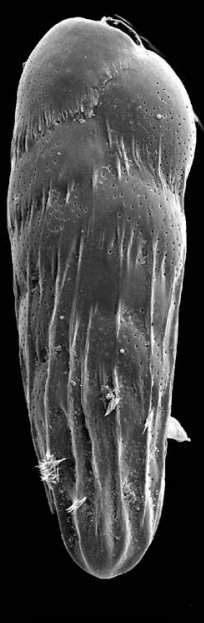

2

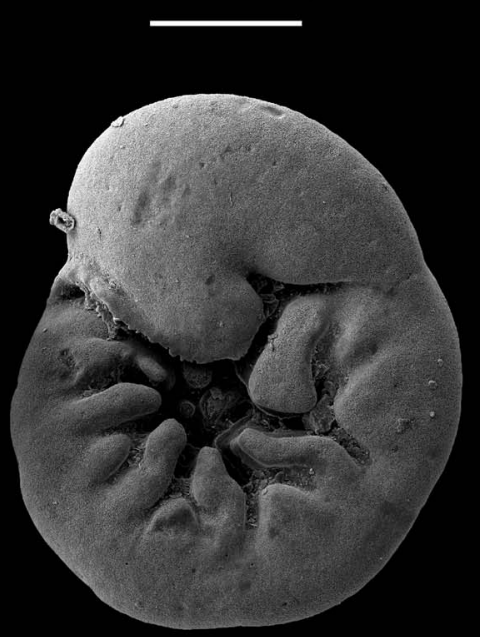

7

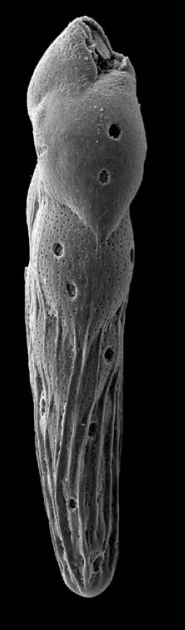

4

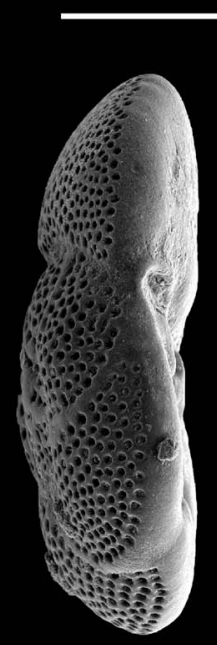

8

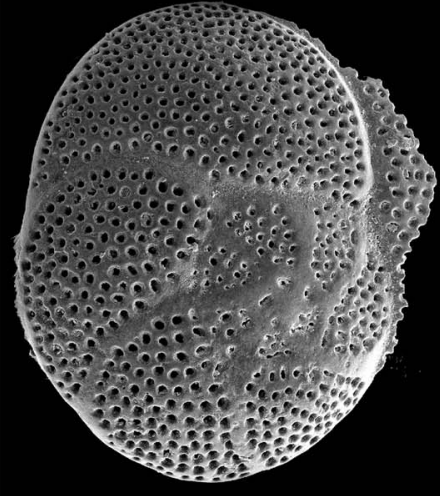

9

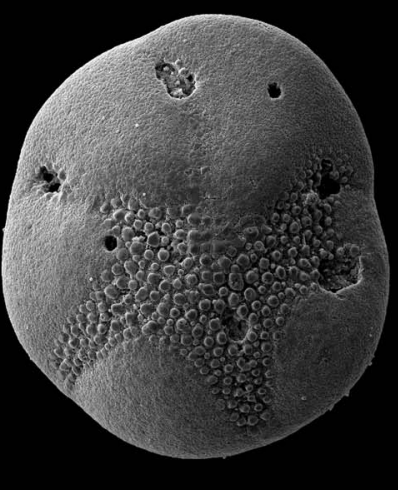

10
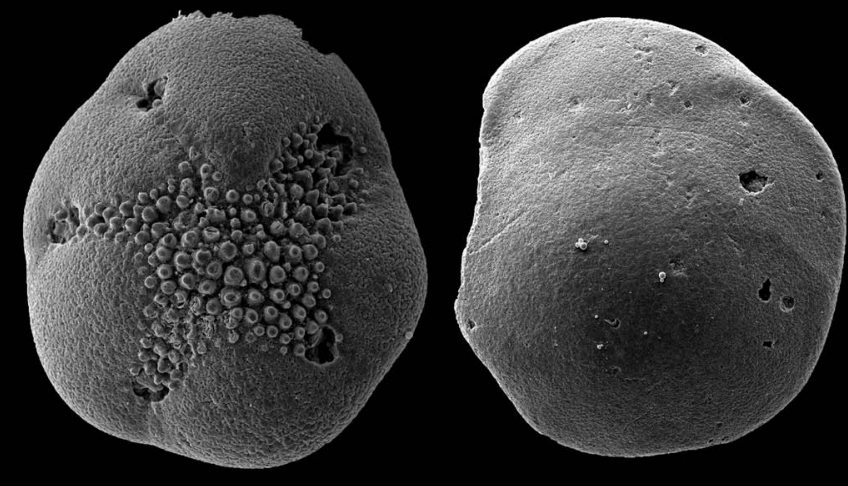

11

Figure 5. SEM photos of the foraminifers from Core CSJA6, Nantong, Jiangsu and Core LZK1, Hengsha Island, Shanghai. All scale bars are $100 \mu \mathrm{m}$. $(\mathbf{1}, \mathbf{2})$ Bolivina robusta: (1) side view, CSJA6, depth 13.2-13.3 m, Reg. No. K1-023; (2) edge view. CSJA6, depth 13.2-13.3 m, Reg. No. K1-025. $(3,4)$ Brizalina striatula: (3) side view, LZK1, depth 12.7-12.8 m, Reg. No. K1-034; (4) edge view, LZK1, depth 12.3-12.4 m, Reg. No. K4-009. $(\mathbf{5}, \mathbf{6})$ Epistominella naraensis: (5) ventral view, right-coiled, LZK1, depth 12.7-12.8 m, Reg. No. K1-067; (6) edge view, left-coiled, LZK1, depth 12.7-12.8 m, Reg. No. K1-069. (7-9) Rosalina bradyi: (7) ventral view, LZK1, depth 30.7-30.8 m, Reg. No. K3-012; (8) edge view, CSJA6, depth 30.8-30.9 m, Reg. No. K4-038; (9) dorsal view, CSJA6, depth 34.2-34.3 m, Reg. No. K3-013. (10-12) Buccella frigida: (10) ventral view, CSJA6, depth $20.8-20.9$ m, Reg. No. K1-036; (11) ventral view, CSJA6, depth 36.2-36.3 m, Reg. No. K4-008; (12) dorsal view, CSJA6, depth 25.5-25.6 m, Reg. No. K1-033. 


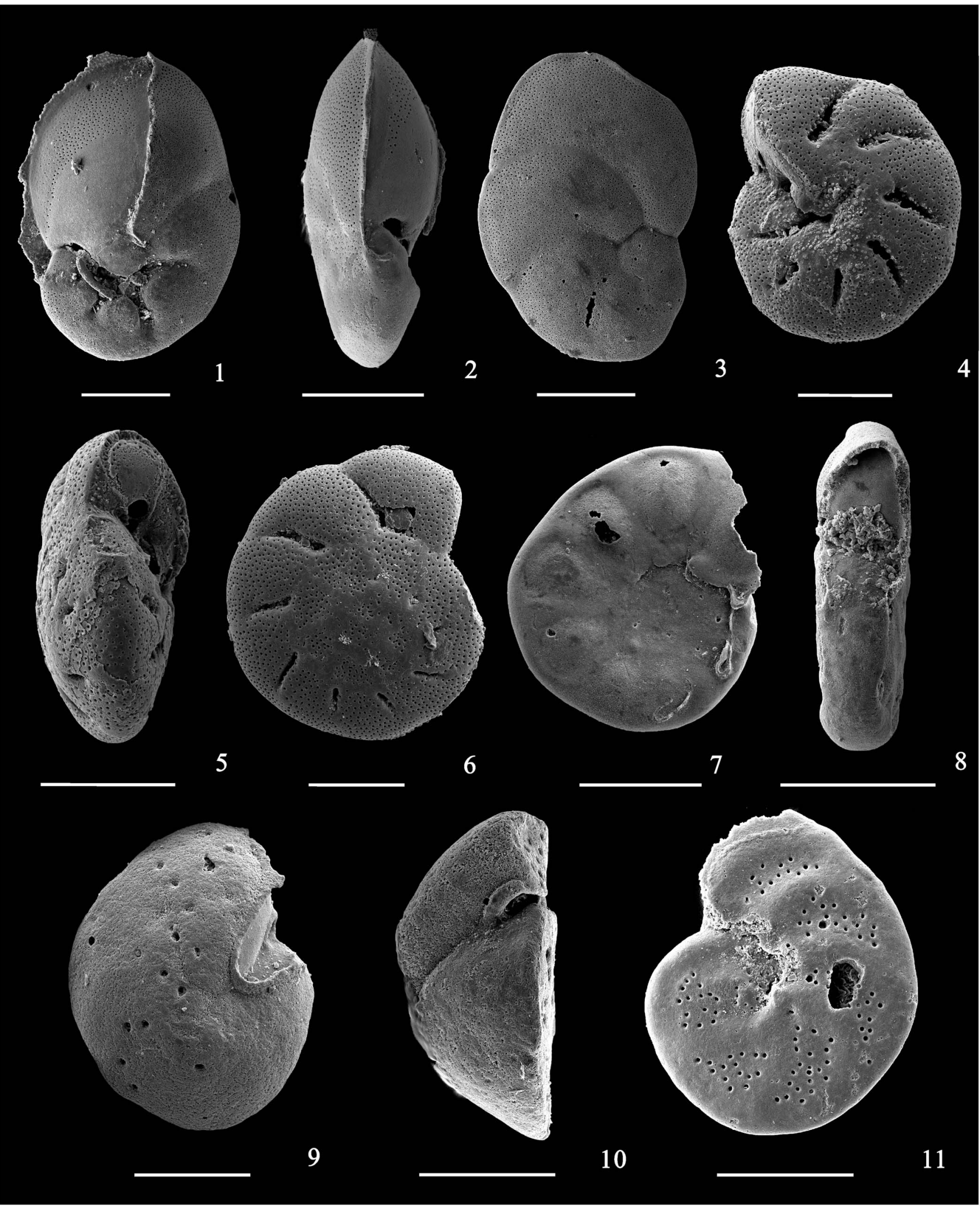

Figure 6. SEM photos of the foraminifers from Core CSJA6, Nantong, Jiangsu and Core LZK1, Hengsha Island, Shanghai. All scale bars are $100 \mu \mathrm{m}$. (1-3) Cancris auriculus: (1) ventral view, CSJA6, depth 34.8-34.9 m, Reg. No. K1-044; (2) edge view, CSJA6, depth 34.8-34.9 m, Reg. No. K1-046; (3) dorsal view, CSJA6, depth 34.8-34.9 m, Reg. No. K1-045. (4-6) Helenina anderseni: (4) ventral view, CSJA6, depth 46.5-46.6 m, Reg. No. K1-029; (5) edge view, CSJA6, depth 46.5-46.6 m, Reg. No. K4-009; (6) dorsal view, CSJA6, depth 46.5-46.6 m, Reg. No. K1-030. (7, 8) Hyalinea balthica: (7) side view, CSJA6, depth 35.2-35.3 m, Reg. No. K4-023; (8) edge view, CSJA6, depth 34.8-34.9 m, Reg. No. K4-024; (9-11) Cibicides lobatulus: (9) ventral view, CSJA6, depth 11.8-11.9 m, Reg. No. K1-047; (10) edge view, CSJA6, depth 17.2-17.3 m, Reg. No. K1-049; (11) dorsal view, CSJA6, depth 7.5-7.6 m, Reg. No. K1-048. 
Gennari et al. (2011) reported a large number of morphological varieties, especially for different shapes of the sutures. The specimens here are more inflated. The supplementary apertures of specimens can be observed on the middle part of the septal sutures instead of near the junction, and are much narrower, showing a deeply incised slit. The supplementary apertures reported by Gennari (2011) are wider near umbilical region, and even triangular.

\section{Family Cibicididae Cushman, 1927 \\ Genus Cibicides de Montfort, 1808 Cibicides lobatulus (Walker and Jacob, 1798) Figure 6.9-6.11}

1798 Nautilus lobatulus Walker and Jacob, p. 642, pl. 14, fig. 36.

1884 Truncatulina lobatulus (Walker and Jacob); Brady, pl. 92, fig.10, pl. 93, figs. 1, 4, 5 .

1931 Cibicides lobatula; Cushman, p. 118, pl. 21, figs. 3a-3c.

1978 Cibicides lobatulus; Cheng and Zheng, p. 232, pl. 21, figs. 2a-2c.

1988 Cibicides lobatulus; Wang et al., p. 162, pl. 25, figs. 12-14.

Holotype.-(BMNH ZF2532) from Challenger Station 172, Friendly Islands, Pacific (33 m ) (Brady, 1884, pl. 92, fig. 10).

Occurrence.-Widely distributed in coastal water of the world oceans; middle and outer shelf of East China Sea and South China Sea (Wang et al., 1988).

Remarks.-Large variations in morphology are assigned to this species. Specimens with keeled periphery or depressed umbilicus were reported by Brady (1884). The specimens here are more inflated with a round periphery, while those of Cushman (1931) and Wang (1988) have compressed chambers with obviously lobulated periphery.

Superfamily Rotaliacea Ehrenberg, 1839

Family Rotaliidae Ehrenberg, 1839

Genus Ammonia Brünnich 1772

Ammonia pauciloculata (Phleger and Parker, 1951)

Figure 7.1-7.3

1951 “Rotalia” pauciloculata Phleger and Parker, p. 23, pl, 12, figs. 8, 9.

1965 Ammonia nantongensis $\mathrm{Ho}, \mathrm{Hu}$, and Wang; $\mathrm{He}, \mathrm{Hu}$, and Wang, p. 104, pl. 11, figs. 5a-5c.

1988 Ammonia pauciloculata; Wang et al., p. 166, pl. 27, figs. 8-10.

Holotype.-(Sample 1) from Core 498 (Phleger and Parker, 1951, pl. 12, figs. 8, 9).

Occurrence.-Gulf of Mexico; coastal water in China seas, inner shelf of East China Sea; Quaternary coastal sediments in China; 0-50m (Wang et al., 1988).

Remarks.-Supplementary apertures that are perpendicular to the middle of the septal sutures on the ventral side, as noted by Wang et al. (1988), can be observed in the holotype illustrated by Phleger and Parker (1951). The specimens in this study and Ammonia nantongensis $\mathrm{Ho}, \mathrm{Hu}$, and Wang (1965) also show this morphological character, while the subspecies Ammonia pauciloculata major described by $\mathrm{He}$ et al. (1965) cannot be assigned to this species because it has a large number of chambers for the last whorl and straight sutures.

Genus Cavarotalia Müller-Merz, 1980

Cavarotalia annectens (Parker and Jones, 1865)

Figure 8.1-8.3

1865 Rotalia beccarii var. annectens Parker and Jones, p. 387 , pl. 19 , figs. $11 \mathrm{a}-11 \mathrm{c}$.

1940 Streblus annectens; Ishizaki, p. 49, pl. 3, figs. 12a, 12b, 13a, 13b.

1965 Ammonia annectens; $\mathrm{He}, \mathrm{Hu}$, and Wang, p. 103, pl. 11, figs. 3a-3c.

1980 Cavarotalia annectens; Müller-Merz, p. 37, figs. 26, 27.

1988 Cavarotalia annectens; Wang et al., p. 168, pl. 27, figs. $12,13$.

Occurrence.-Miocene in India; shallow water in Pacific and Indian oceans; shelf of China seas; Quaternary in Taiwan, China; Quaternary coastal sediments in East China; 0-50 m, East China Sea (Wang et al., 1988).

Remarks.-Deeply incised, fishbone-like sutures taper from the middle to the periphery in ventral side. The large transparent umbilical plug also distinguishes it from Ammonia.

Family Elphidiidae Galloway, 1933

Genus Cribrononion Thalmann, 1947

Cribrononion subincertum (Asano, 1950)

Figure 8.4, 8.5

1950 Elphidium subincertum Asano, p. 10, figs. 56, 57.

1965 Cribrononion gnythosuturatum; He et al., p. 115, pl. 14, figs. 5a, 5b.

1965 Cribrononion sp.; He et al., p. 115, pl. 14, figs. 3a, 3b.

1978 Cribrononion incertum; Zheng et al., p. 58, pl. 8, figs. $15,16$.

1980a Cribrononion subincertum; Wang et al., pl. 9, figs. 22, 23.

1988 Cribrononion subincertum; Wang et al., p. 168, pl. 28, figs. 1-4.

Occurrence.- Shallow water in high-latitude North Pacific and North Atlantic; Recent and Quaternary coastal sediments in Bohai Sea, Yellow Sea, and East China Sea; 0-50m in East China Sea; 10-30\% salinity, coastal water off Jiangsu and Zhejiang, China (Wang et al., 1988).

Remarks.-The specimens in this study possess the long slit sutures. Test slightly compressed, as show in Figure 8.4, or inflated (Fig. 8.5). Wang et al. (1988) pointed out that the juvenile forms are often more inflated than the adult. It was reported that the aperture is made up of a row of pores (He et al., 1965). Due to the granular cover on the base of the apertural face, the pores cannot be observed in the specimens illustrated here. 


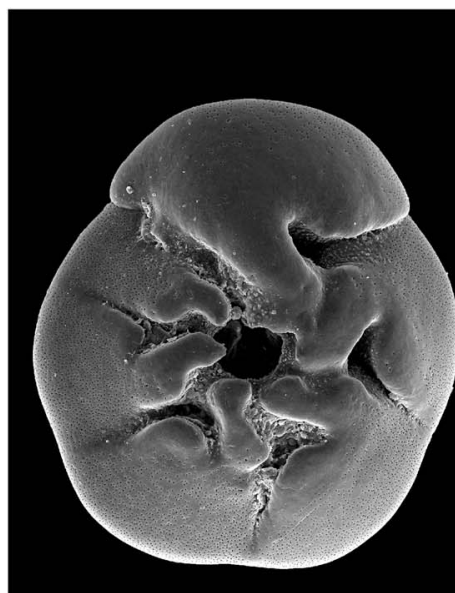

1

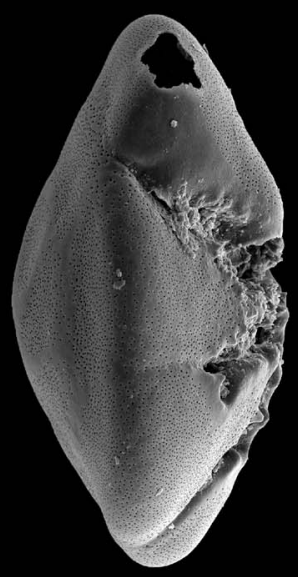

2

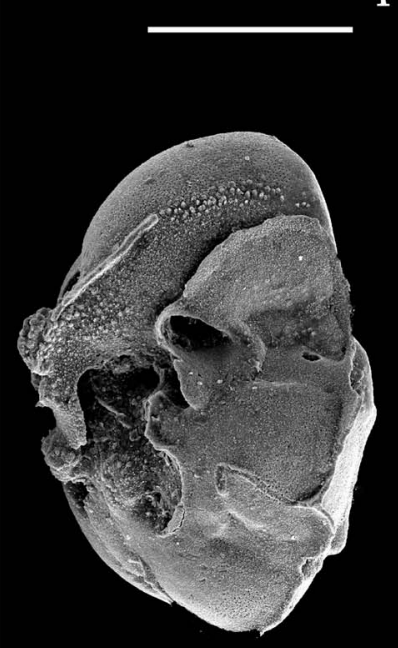

5

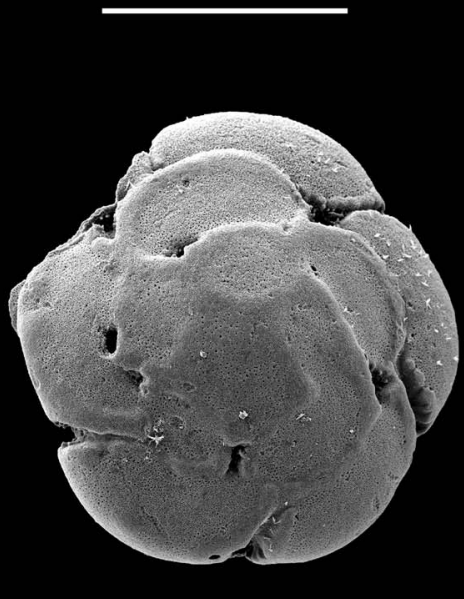

6

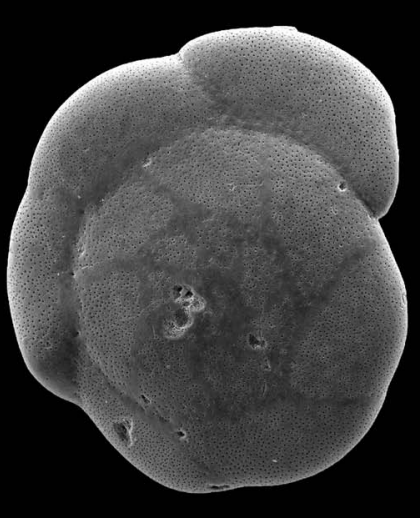

3

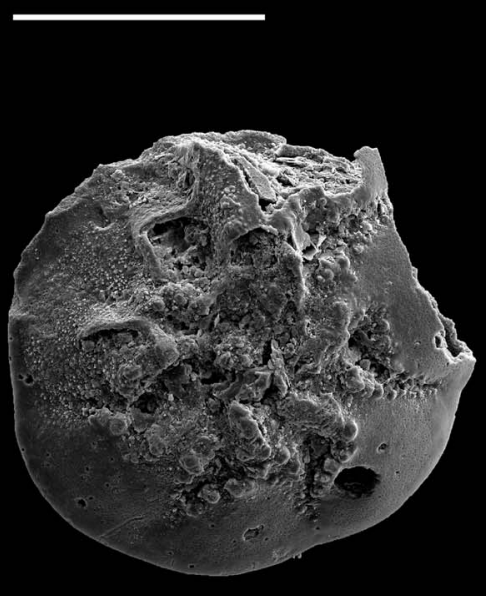

7

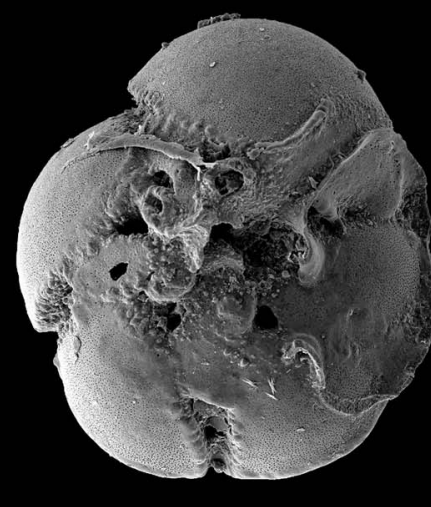

3
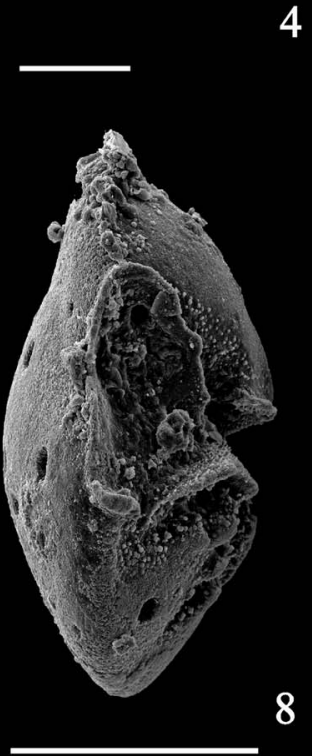

8

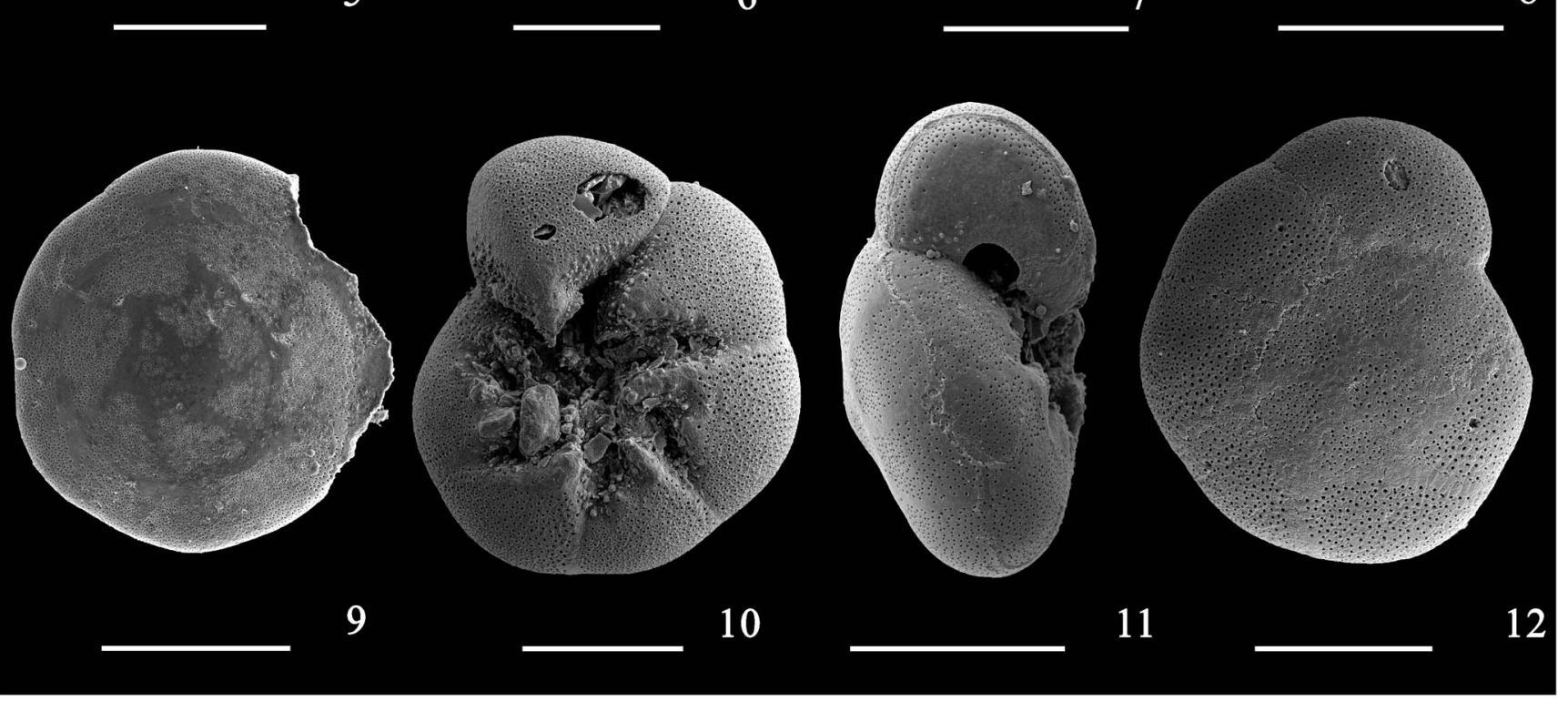

Figure 7. SEM photos of the foraminifers from Core CSJA6, Nantong, Jiangsu and Core LZK1, Hengsha Island, Shanghai. All scale bars are 100 $\mu$ m. (1-3) Ammonia pauciloculata: (1) ventral view, CSJA6, depth 31.2-31.3 m, Reg. No. K4-003; (2) edge view, LZK1, depth 27.7-27.8 m, Reg. No. K4-005; (3) dorsal view, CSJA6, depth 31.2-31.3 m, Reg. No. K4-004. (4-6) Ammonia compressiuscula: (4) ventral view, CSJA6, depth 34.2-34.3 m, Reg. No. K1-018; (5) edge view, CSJA6, depth 34.2-34.3 m, Reg. No. K1-019; (6) dorsal view, CSJA6, depth 21.5-21.6 m, Reg. No. K1-017. (7-9) Ammonia ketienziensis: (7) ventral view, CSJA6, depth 33.8-33.9 m, Reg. No. K4-035; (8) edge view, CSJA6, depth 34.2-34.3 m, Reg. No. K4-034; (9) dorsal view, CSJA6, depth 34.2-34.3 m, Reg. No. K4-033. (10-12) Ammonia beccarii: (10) ventral view, CSJA6, depth 7.5-7.6 m, Reg. No. K1-007; (11) edge view, CSJA6, depth 7.5-7.6 m, Reg. No. K1-009; (12) dorsal view, CSJA6, depth 7.5-7.6 m, Reg. No. K1-008. 


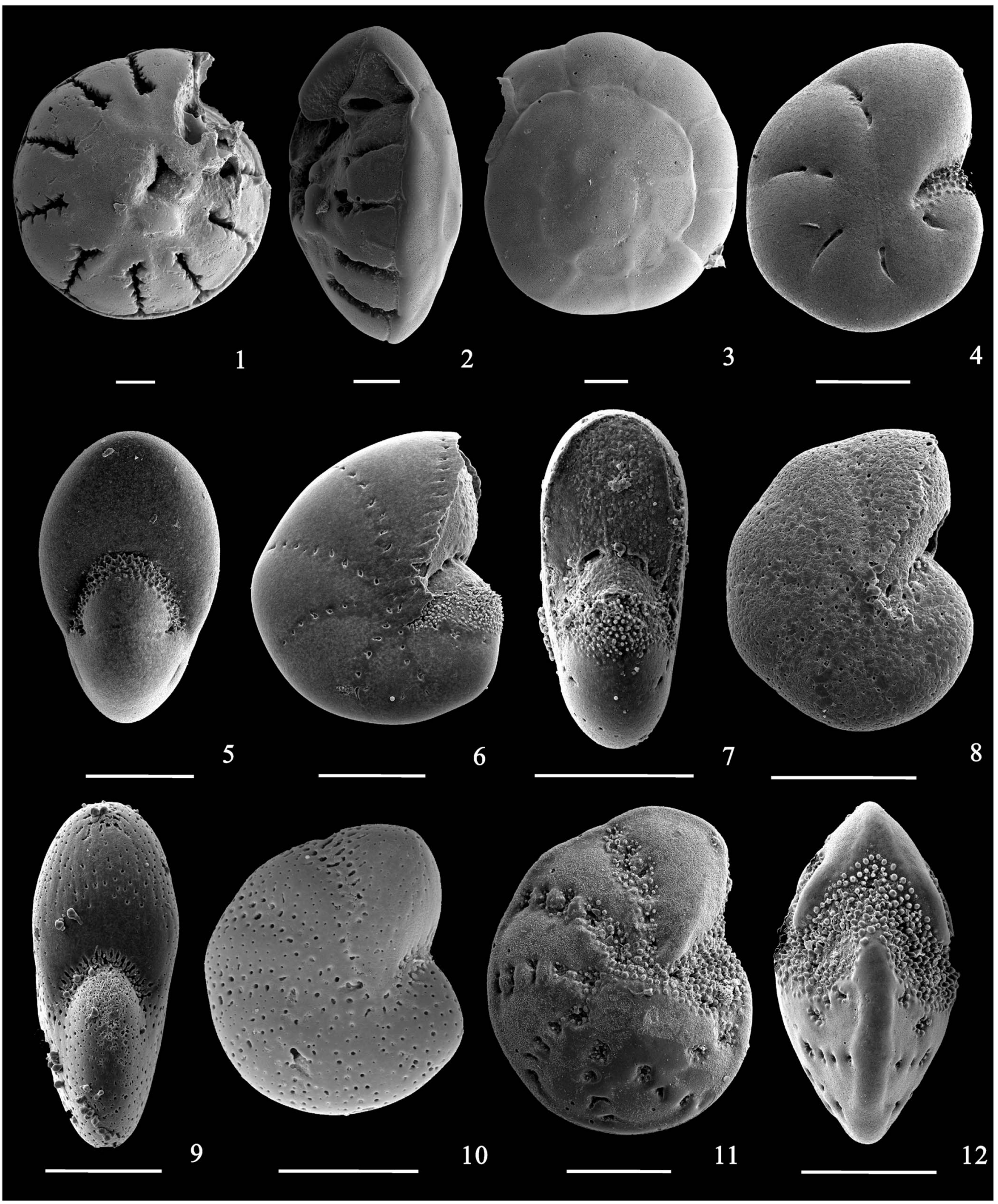

Figure 8. SEM photos of the foraminifers from Core CSJA6, Nantong, Jiangsu and Core LZK1, Hengsha Island, Shanghai. All scale bars are $100 \mu \mathrm{m}$. (1-3) Cavarotalia annectens: (1) ventral view, LZK1, depth 21.7-21.8 m, Reg. No. K1-004; (2) edge view, LZK1, depth 21.7-21.8 m, Reg. No. K4-001; (3) dorsal view, LZK1, depth 21.7-21.8 m, Reg. No. K1-005. (4, 5) Cribrononion subincertum: (4) side view, CSJA6, depth 23.2-23.3 m, K4-012; (5) edge view, CSJA6, depth 23.2-23.3 m, Reg. No. K4-013. (6, 7) Cribrononion vitreum: (6) side view, CSJA6, depth 23.2-23.3 m, Reg. No. K4-014; (7) edge view, LZK1, depth 12.3-12.4 m, Reg. No. K4-015. (8-10) Elphidiella kiangsuensis: (8) side view, CSJA6, depth 23.2-23.3 m, Reg. No. K4-026; (9) edge view, CSJA6, depth 5.5-5.6 m, Reg. No. K1-055. (10) side view (Guo et al., 2014). (11, 12) Elphidium advenum: (11) side view, CSJA6, depth 47.6-47.7 m, Reg. No. K1-056; (12) edge view, CSJA6, depth 47.6-47.7 m, Reg. No. K1-057. 
Cribrononion vitreum $\mathrm{W}$ ang and $\mathrm{Gu}, 1980$

Figure 8.6, 8.7

1980 Cribrononion vitreum; Wang and Gu, pl. 16, fig. 13.

1988 Cribrononion vitreum; Wang et al., p. 169, pl. 27, figs. 14, 15.

2012 Cribrononion vitreum; $\mathrm{Li}$ et al., pl. 2, figs. 11, 12.

Holotype.-(TJU H1560) from Core Lp25, depth 24-35.91 m, east coast of Liaohe estuary, Panshan, Liaoning Province (Wang and $\mathrm{Gu}, 1980$, pl. 16, fig. 13).

Occurrence.-Recent and Quaternary coastal sediments of Bohai Sea, East China Sea, and Yellow Sea; inner shelf and estuary in East China Sea, 10-30\% salinity (Wang et al., 1988).

Remarks.-Wang et al. (1988) pointed out that there are several pores on the middle of the aperture face, which also has been observed by Li et al. (2012). The specimens illustrated here have lost the last chamber. But the aperture, a row of slits, is the same as those described by Wang et al. (1988). The pores on the aperture face in this study cannot be observed.

Genus Elphidiella Cushman, 1936a

Elphidiella kiangsuensis (Ho, Hu, and Wang, 1965)

Figure 8.8-8.10

1965 Cribrononion kiangsuensis $\mathrm{Ho}, \mathrm{Hu}$, and Wang; $\mathrm{He}, \mathrm{Hu}$, and Wang, p. 114, pl. 13, fig. 13.

1978 Elphidiella kiangsuensis; Zheng et al., p. 60, pl. 9, figs. 1, 13.

1988 Elphidiella kiangsuensis; Wang et al., p. 171, pl. 29, figs. 12, 13.

2014 Elphidiella kiangsuensis; Guo et al., pl. 1, figs. 5, 6.

Holotype.-(NIGP 14685) from Binhai, Jiangsu, China (He et al., pl. 13, fig. 13).

Description.-Test planspiral, entirely involute, oval in side view, bilaterally symmetrical, sides nearly parallel in edge view; periphery rounded; chambers 8-10 in the last whorl, increasing gradually, gently inflated; umbilicus flattened; sutures curved, nearly flush with the surface, often consisting of two rows of small round pores; wall smooth, translucent, finely perforate; oval apertural face; aperture comb-like on the base of the face.

Occurrence.-Quaternary and Recent coastal sediments in Bohai Sea, Yellow Sea and East China Sea (Wang et al., 1988).

Remarks.-The pores in the sutures of specimens in this study are less distinct, the same as shown by He et al. (1965). The suture pores are more clear in the specimens (Fig. 8.10) reported by Guo et al. (2014), in which two rows of pores form a wide suture zone. Depressed slit-like sutures also were reported in the East China Sea (Wang et al., 1988).

Genus Elphidium de Montfort, 1808

Elphidium hispidulum Cushman, 1936b

Figure 9.1, 9.2 1936b Elphidium hispidulum Cushman, p. 83, pl. 14, figs. 13a, 13b.

1978 Elphidium hispidulum; Zheng et al., p. 55, pl. 7, fig. 9.

1988 Elphidium hispidulum; Wang et al., p. 170, pl. 29, figs. 16, 17.

Holotype.-(USNM CC 23028) from 7-26 m, Albany Passage, Australia (Cushman, 1936b, pl. 14, figs. 13a, 13b).

Occurrence.-Southern Australia and Gulf of Paria; surface sediments in Bohai Sea, Yellow Sea and East China Sea.

Remarks.-The bosses in the umbilicus are partially separated for specimens in this study. A row of low papillae in the early portion of the sutures is more distinct than those of Wang et al. (1988) and He et al. (1965).

Elphidium magellanicum Heron-Allen and Earland, 1932 Figure 9.4, 9.5

1932 Elphidium (Polystomella) magellanicum Heron-Allen and Earland, p. 440, pl. 16, figs. 26-28.

1978 Elphidium magellanicum; Zheng et al., p. 56, pl. 8, fig. 3. 1978 Elphidiononion magellanicum; Banner and Culver, pl. 9, fig. 16.

1980b Elphidium magellanicum; Wang et al., p. 98, pl. 11, fig. 16. 1988 "Elphidium magellanicum"; Wang et al., p. 169, pl. 28, figs. 5, 11-13.

Holotype.-(BMNH HA508-90) from WS 89, depth $23 \mathrm{~m}$, eastern entrance to the Straits of Magellan (Heron-Allen and Earland, pl. 16, figs. 26-28).

Occurrence.-Coastal water and Quaternary coastal sediments in Bohai Sea, Yellow Sea, and East China Sea (Wang et al., 1988).

Remarks. - Wang et al. (1988) pointed out that the specimens in the East China Sea are different from those of the Atlantic samples by a much inflated test. The specimens in this study have a less lobulate peripheral edge, close to that reported by Wang et al. (1988). The umbilicus and the base of the apetural face are filled with fine granular matter in this study, but the granular region is much narrower and smaller than those described by Heron-Allen and Earland (1932).

Genus Protelphidium Haynes, 1956 Protelphidium tuberculatum (d'Orbigny, 1846)

Figure 9.6, 9.7

1846 Nonion tuberculatum d'Orbigny, p. 108, pl. 5, figs. 13, 14.

1939 Nonion tuberculatum; Cushman, p. 13, pl. 3, figs. 12, $16,17$.

1980a Protelphidium tuberculatum; Wang and Gu, p. 60, pl. 16, fig. 7.

1988 Protelphidium tuberculatum; Wang et al., p. 171, pl. 29, figs. 14, 15. 


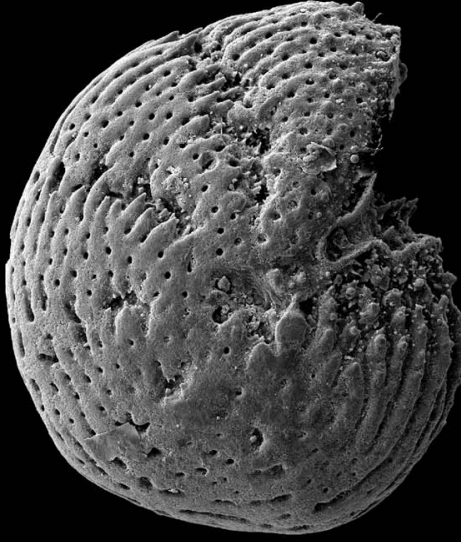

1

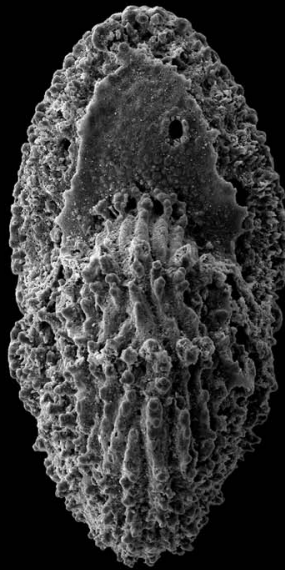

2

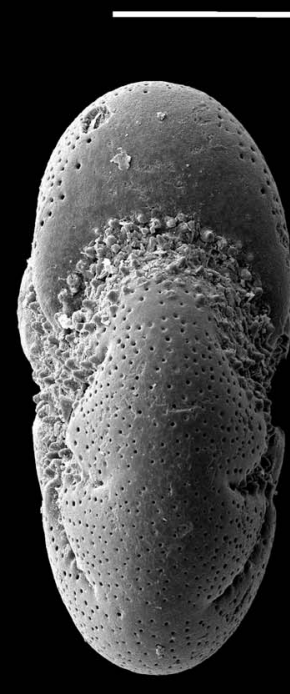

5
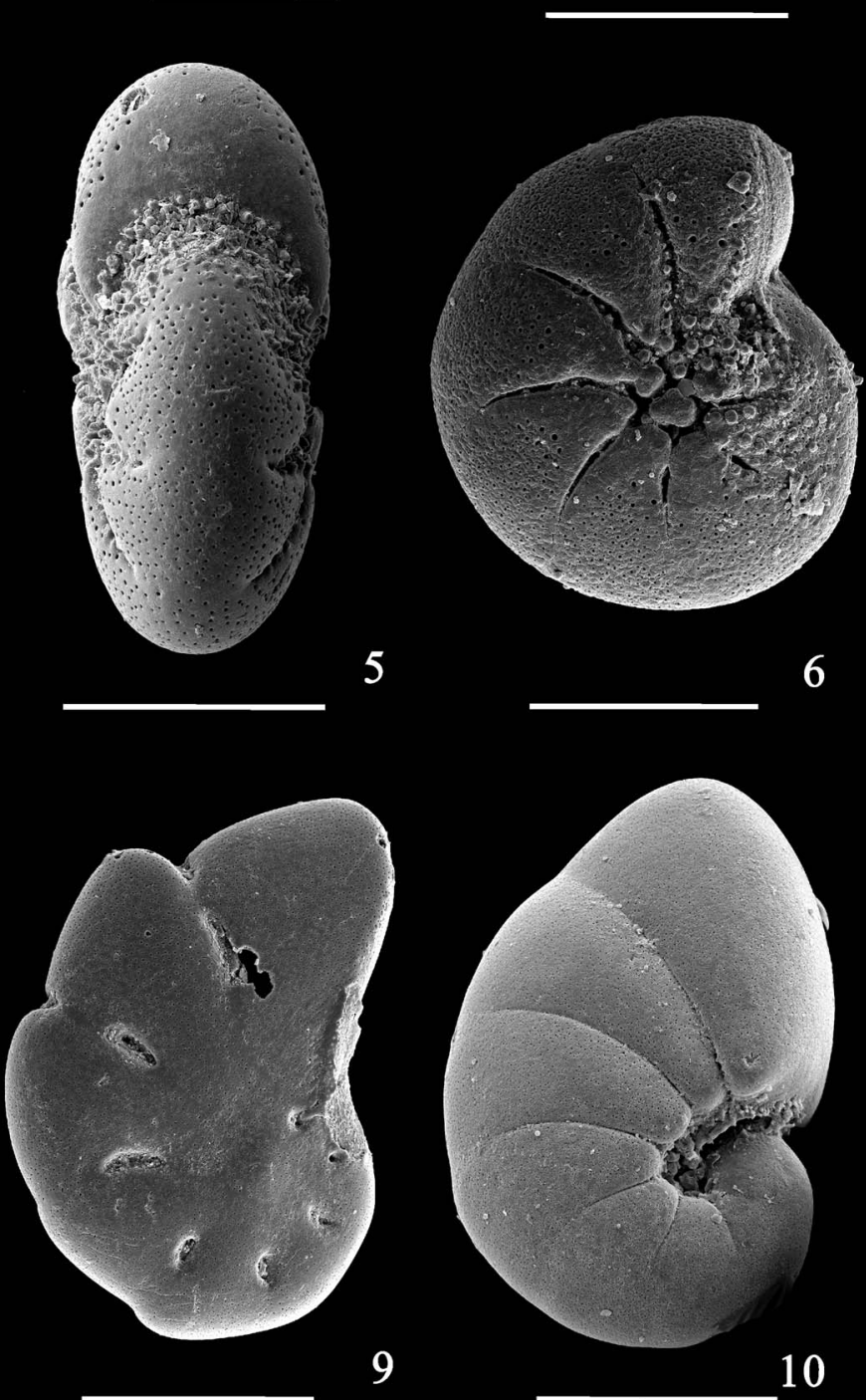

9

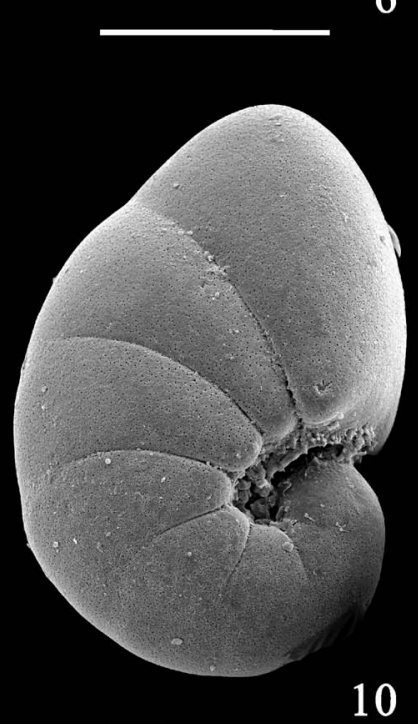

10

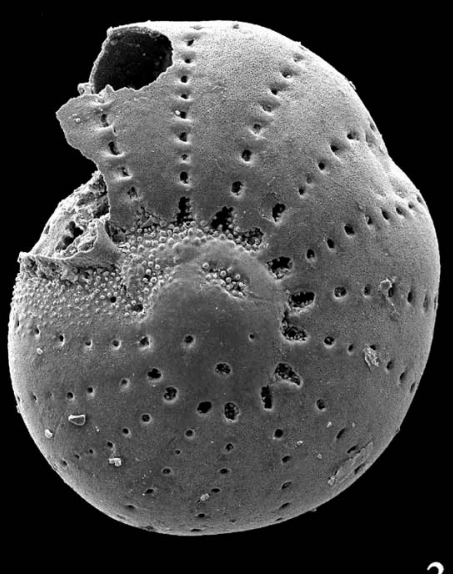

3

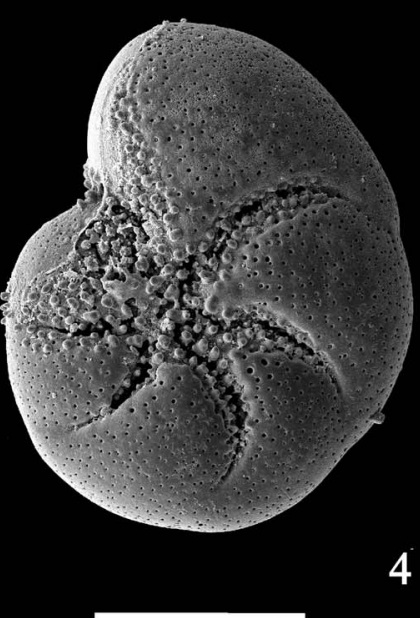

4
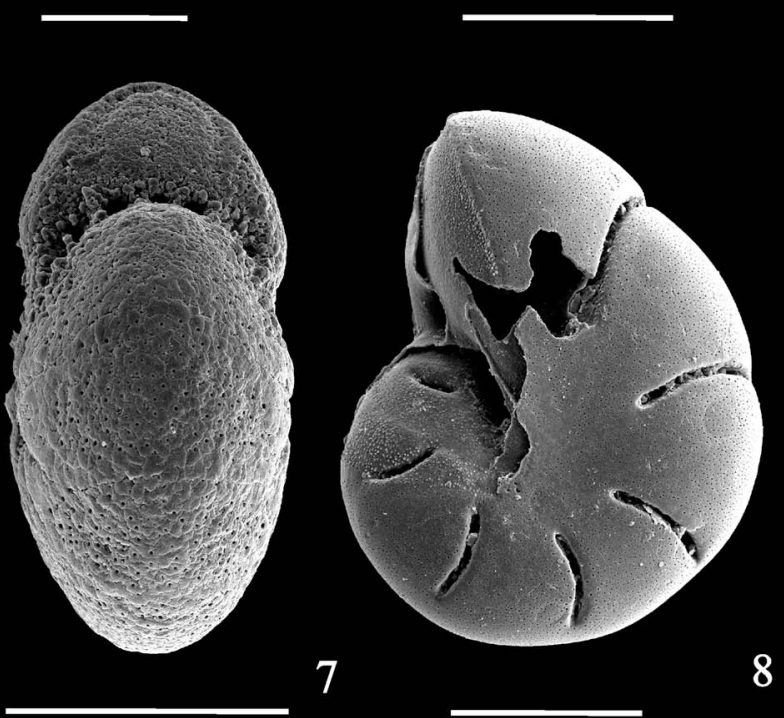

8

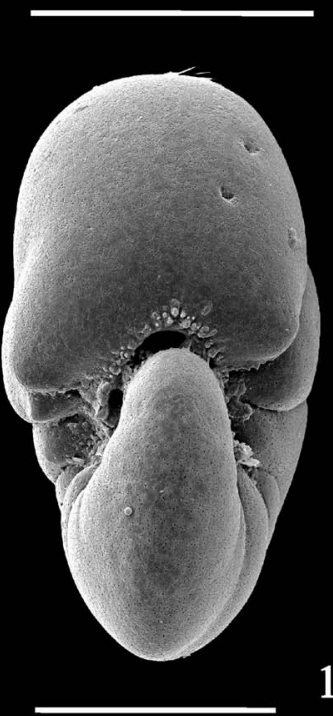

11

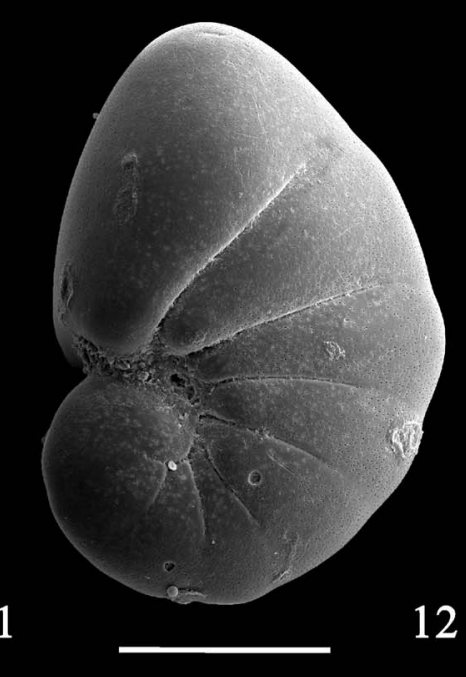

12

Figure 9. SEM photos of the foraminifers from Core CSJA6, Nantong, Jiangsu and Core LZK1, Hengsha Island, Shanghai. All scale bars are $100 \mu \mathrm{m}$. (1, 2) Elphidium hispidulum: (1) side view, CSJA6, depth 46.5-46.6m, Reg. No. K1-060; (2) edge view, CSJA6, depth 25.5-25.6 m, Reg. No. K4-029. (3) Elphidium limpidum: side view, CSJA6, depth 46.5-46.6 m, Reg. No. K1-062. (4, 5) Elphidium magellanicum: (4) side view, CSJA6, depth 2.2-2.3 m, Reg. No. K1-065; (5) edge view, CSJA6, depth 20.8-20.9 m, Reg. No. K1-066. (6, 7) Protelphidium tuberculatum: (6) side view, CSJA6, depth 13.5-13.6 m, Reg. No. K2-022; (7) edge view, CSJA6, depth 25.5-25.6 m, Reg. No. K2-023. (8, 9) Pseudononionella variabilis: (8) ventral view, CSJA6, depth 7.5-7.6 m Reg. No. K2-024; (9) dorsal view, CSJA6, depth 36.8-36.9 m, Reg. No. K2-025. (10-12) Florilus scaphus: (10) ventral view, LZK1, depth 12.3-12.4 m, Reg. No. K1-076; (11) edge view, LZK1, depth 12.3-12.4 m, Reg. No. K1-078; (12) dorsal view, LZK1, depth 12.7-12.8 m, Reg. No. K4-022. 
Occurrence.-Coastal water and Quaternary coastal sediments in Bohai Sea, Yellow Sea, and East China Sea; Yellow Sea coastal cold water; inner shelf and Late Pleistocene outer shelf sediments in East China Sea (Wang et al., 1988).

Remarks.-This species differs from Elphidium magellanicum by a small elevated umbilicus filled with a few tuberculations, and evident slit sutures. It was reported that the early whorls in this species usually appears yellow in China seas (Wang et al., 1988).

Superfamily Cassidulinacea d'Orbigny, 1839a

Family Caucasinidae Bykova, 1959

Genus Fursenkoina Loeblich and Tappen, 1961

Fursenkoina pauciloculata (Brady, 1884)

Figure 10.1, 10.2

1884 Virgulina pauciloculata Brady, p. 414, pl. 52, figs. 4, 5. 1965 Fursenkoina pauciloculata; $\mathrm{He}, \mathrm{Hu}$, and Wang, p. 84, pl. 6, fig. 7.

1994 Virgulina pauciloculata Brady; Jones, pl. 52, figs. 4, 5.

Occurrence.-Recent South Pacific; Jiangsu, China (He et al., 1965).

Remarks. - The shorter and wider specimens (Fig. 10.1) reported here are the same as those described by He et al. (1965); the elongate specimen (Fig. 10.2) is referred to those specimens described by Brady (1884), but lacks the short spine in the earliest chamber.

Superfamily Nonionacea Schultze, 1854

Family Nonionidae Schultze, 1854

Genus Nonionella Cushman, 1926

Nonionella jacksonensis Cushman, 1933

Figure 10.5, 10.6

1933 Nonionella jacksonensis Cushman, p. 10, pl. 1, figs. 23a-23c.

1965 Nonionella jacksonensis; He, Hu, and Wang, p. 119, pl. 14, figs. 11a, $11 \mathrm{~b}$.

1988 Nonionella jacksonensis; Wang et al., p. 176, pl. 32, figs. $1,2$.

Holotype.-(USNM MO 371678) from Cooper marl, $1.6 \mathrm{~km}$ (1 mile) south of Moncks Corner, Berkeley Co., S.C. (Cushman, 1933, pl. 1, figs. 23a-23c).

Occurrence.-Upper Eocene in U.S.A.; surface shelf and Quaternary coastal sediments in Yellow Sea and East China Sea; common in inner shelf and estuary of East China Sea (Wang et al., 1988).

Remarks.-It was reported that there is a slit-like aperture on the base of last chamber (He et al., 1965). The aperture of specimens presented here cannot be observed due to the granular cover on the base of the apertural face. The latter chambers in this study increase slowly, comparatively.

\section{Results}

Foraminiferal specimens were only found from the depth intervals of 3-42.07 $\mathrm{m}, 1.8-65.7 \mathrm{~m}$, and $0.6-46.1 \mathrm{~m}$ in cores ZKA4, CSJA6 and LZK1, respectively (Fig. 2). The foraminiferal abundance in Core ZKA4 is generally lower than those of the other two cores (Fig. 2). In cores CSJA6 and LZK1, the average abundance of benthic foraminifers is 50 and 33 specimens $150 \mathrm{~g}$, respectively. In Core LZK1, the highest benthic foraminiferal abundance is 718 specimens $/ 50 \mathrm{~g}$ at $13 \mathrm{~m}$ depth, while in Core CSJA6, the highest of benthic foraminiferal abundance is 385 specimens $/ 50 \mathrm{~g}$ at $46.6 \mathrm{~m}$ depth. Most of the foraminifers are benthic forms, with planktonic types being $<5 \%$ in each core.

Benthic foraminiferal species diversity trend is similar to the abundance trend, varying from a low of 20 in Core ZKA4 to 35-46 in cores CSJA6 and LZK1. The middle and upper parts of the Rudong Formation in the three cores have higher foraminiferal abundance and diversity. Of the benthic foraminifers, 115 species in 53 genera have been identified, most of which are hyaline tests. The porcellaneous forms are frequent in some layers, and arenaceous forms are occasionally observed.

The dominant species in the three cores is Ammonia beccarii var., which approaches $50 \%$ on average. Other species, such as Ammonia compressiusula, Ammonia ketienziensis, Ammonia pauciloculata, Cribrononion subincertum, Elphidium advenum, Elphidium magellanicum, and Florilus decorus are also present at high frequency. Some species, such as Hazawaia nipponica and Melonis barleeanum, are seldom found (Fig. 11).

\section{Discussion}

Based on the occurrences of benthic foraminifers in the cores, three assemblages can be recognized (Fig. 2). In Core CSJA6, for example, the three foraminiferal assemblages are, in ascending order, the Ammonia beccarii-Florilus decorus assemblage, the Ammoina beccarii-Elphidium advenum assemblage, and the Ammonia beccarii-Elphidium magellanicum assemblage (Figs. 2, 12).

The lower parts of the cores (below $42.07 \mathrm{~m}, 34 \mathrm{~m}$, and $52.9 \mathrm{~m}$ for ZKA4, LZK1, and CSJA6, respectively) are characterized by lower foraminiferal abundance and diversity, dominated by Ammonia beccarii var. and Florilus decorus. In addition, Cribrononion subincertum, Elphidium advenum, and Elphidium magellanicum occur in moderate abundance, indicating a hypohaline, low-temperature water environment. The Ammonia beccarii-Florilus decorus assemblage is comparable with the Ammonia beccarii assemblage of the lower part of Bed H I -1 in the South Yellow Sea shelf, both of which have low foraminiferal abundance and diversity (Yang, 1985, 1993; Yang and Lin, 1996).

The foraminifers are abundant and more diverse in the middle parts of the cores (depth intervals of $3-42.07 \mathrm{~m}$, 12-34 m, and 19.9-52.9 $\mathrm{m}$ for ZKA4, LZK1, and CSJA6, respectively), where the shallow-water species Ammoina beccarii var. and Elphidium advenum are dominant. In this interval, the porcellaneous benthic foraminfers are often relatively common. Cavarotalia annectens and Pararotalia nipponica are 

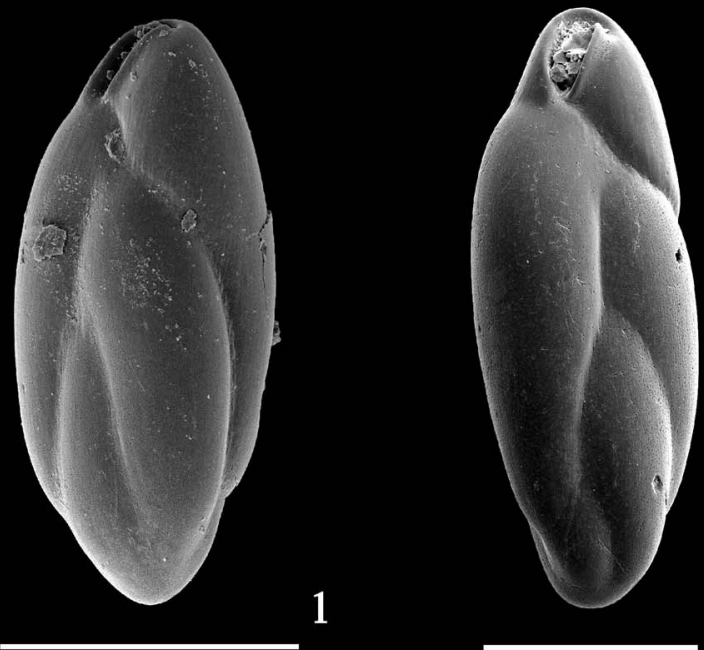

2
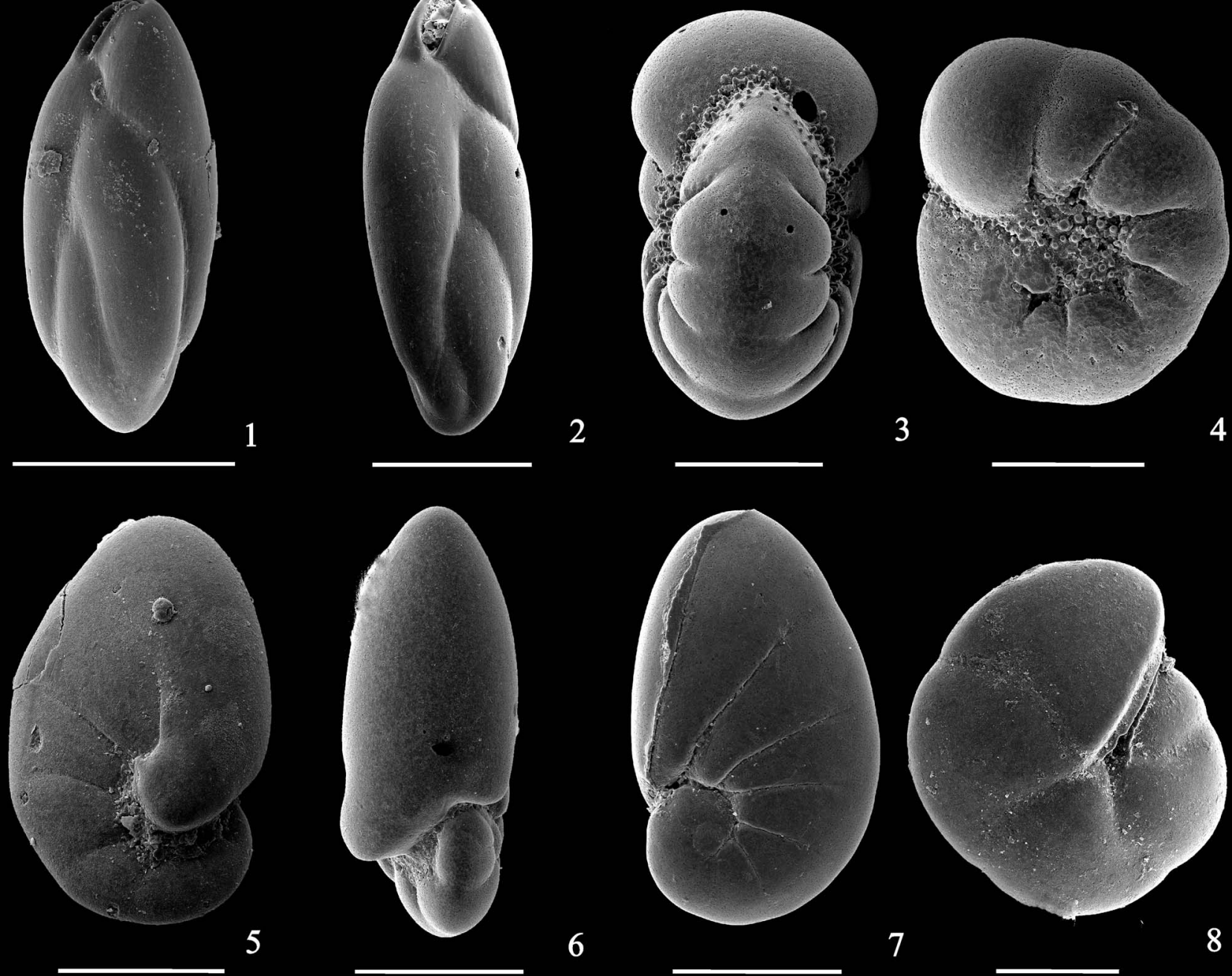

6
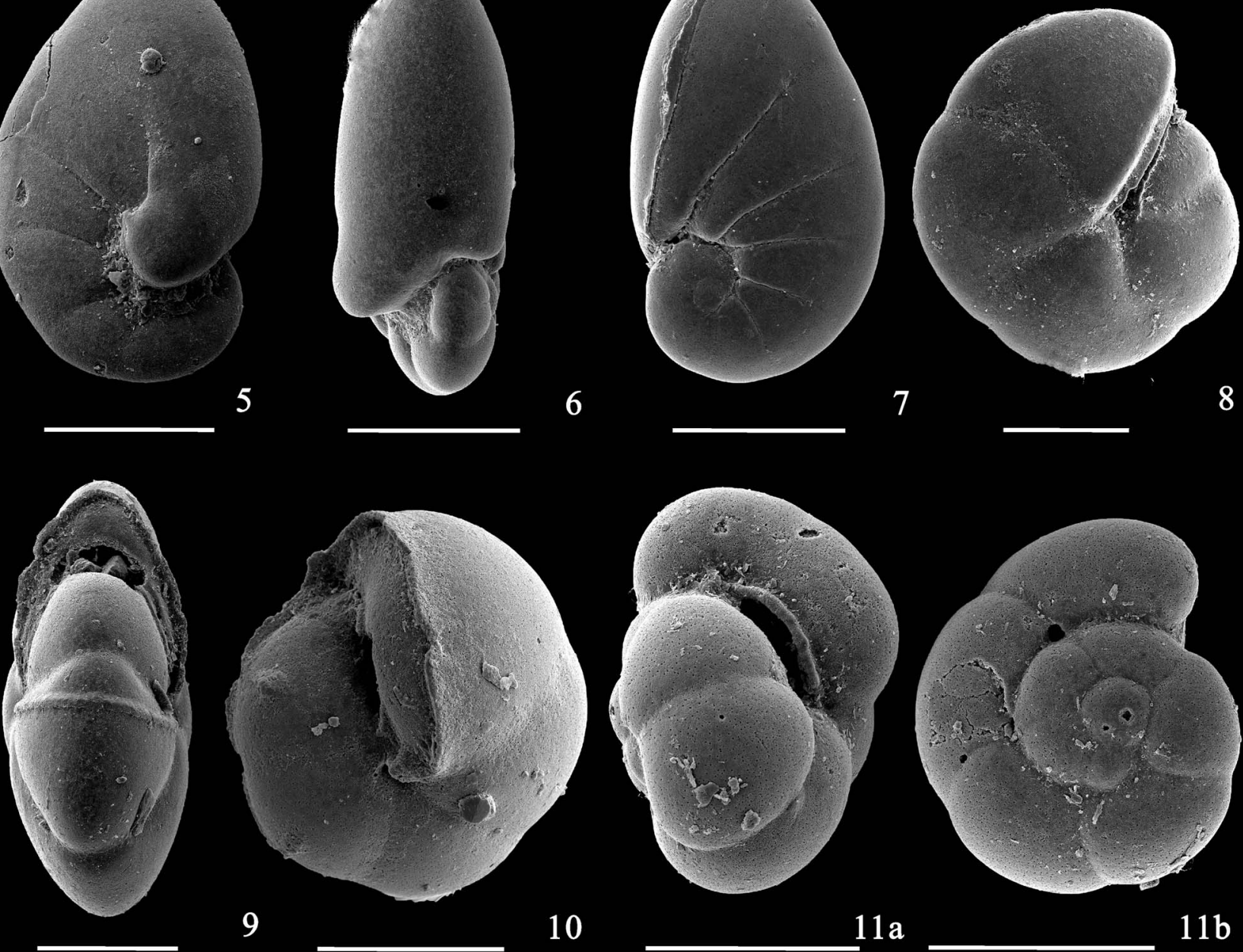

Figure 10. SEM photos of the foraminifers from Core CSJA6, Nantong, Jiangsu and Core LZK1, Hengsha Island, Shanghai. All scale bars are $100 \mu \mathrm{m}$ $(\mathbf{1}, \mathbf{2})$ Fursenkoina pauciloculata: (1) side view, CSJA6, depth 34.8-34.9 m, Reg. No. K1-086; (2) apertural view, LZK1, depth 25.5-25.6 m, Reg. No. K3-023. $(\mathbf{3}, \mathbf{4})$ Nonion akitense: $(3)$ side view, CSJA6, depth 23.2-23.3 m, K2-011; (4) edge view, CSJA6, depth 23.2-23.3 m, Reg. No. K2-012. (5-7) Nonionella jacksonensis: (5) ventral view, LZK1, depth 12.3-12.4 m, Reg. No. K2-015; (6) edge view, LZK1, depth 12.3-12.4 m, Reg. No. K2-013; (7) dorsal view, LZK1, depth 12.7-12.8 m, Reg. No. K2-014. (8, 9) Pullenia quinqueloba: (8) side view, ZKA4, depth 41.1-41.2 m, Reg. No. K2-027; (9) edge view, LZK1, depth 4.5-4.6m, Reg. No. K2-028. (10, 11) Gyroidina nippoinca: (10) ventral view, LZK1, depth 19.8-19.9 m, Reg. No. K1-089; (11a) edge view, LZK1, depth 5.1-5.2 m, Reg. No. K1-090; (11b) dorsal view, LZK1, depth 5.1-5.2 m, Reg. No. K1-090. 


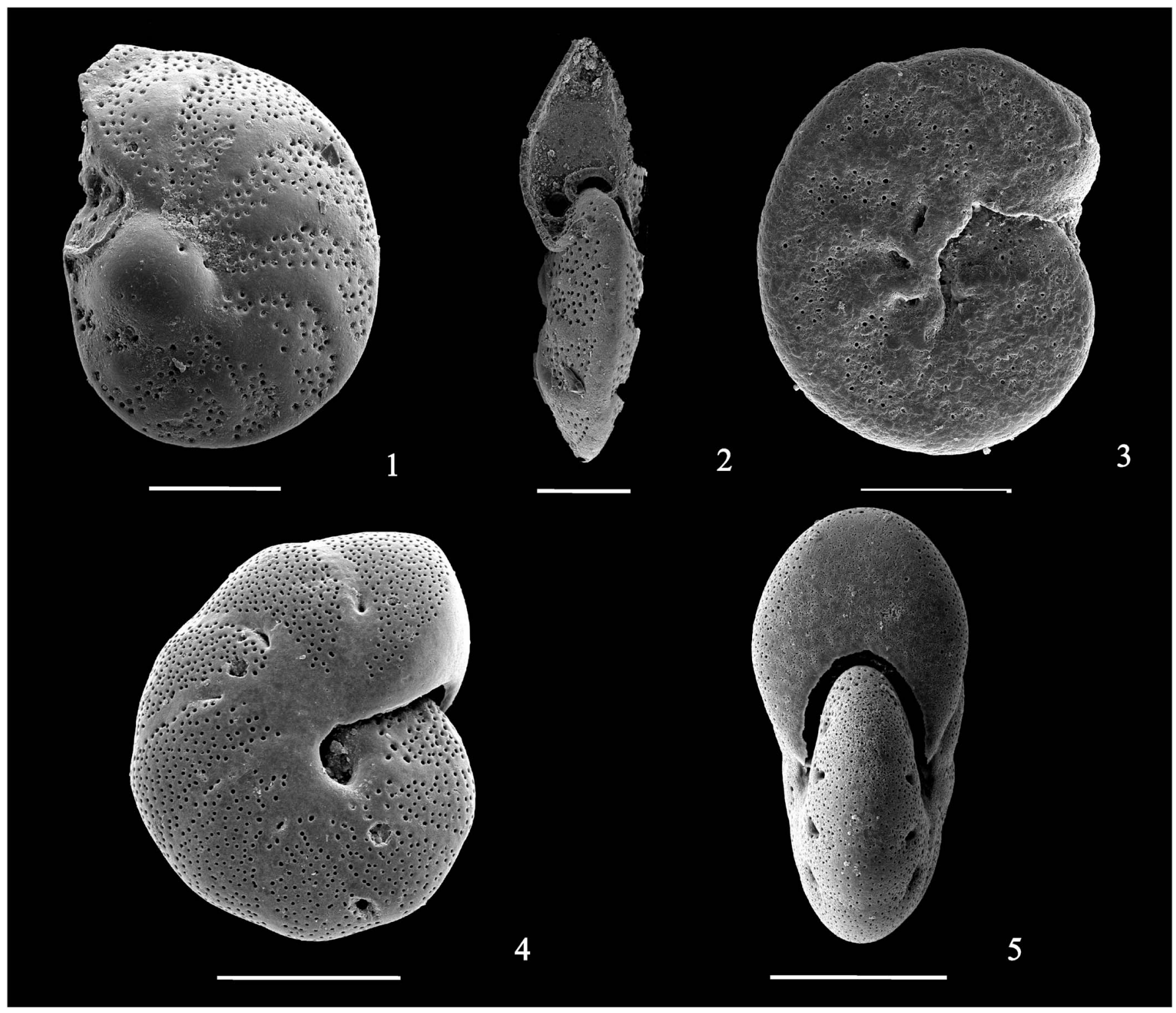

Figure 11. SEM photos of the foraminifers from Core CSJA6, Nantong, Jiangsu; Core ZKA4, Yangzhou, Jiangsu; and Core LZK1, Hengsha Island, Shanghai. (1-3) Hazawaia nipponica: (1) ventral view, LZK1, depth 26.9-27.0 m, Reg. No. K1-092; (2) edge view, CSJA6, depth 47.6-47.7 m, Reg. No. K1-094; (3) dorsal view, CSJA6, depth 21.5-21.6m, Reg. No. K1-093. (4, 5) Melonis barleeanum: (4) side view, CSJA6, depth 23.2-23.3 m, Reg. No. K2-009; (5) edge view, CSJA6, depth 23.2-23.3 m, Reg. No. K2-010.

relatively abundant. For example, the Cavarotalia annectens content is up to $18 \%$ at the depth $32.2-32.3 \mathrm{~m}$ in Core CSJA6. The benthic foraminifers were typical of warm-water forms. This is corroborated by the relative large size of the foraminiferal tests, which also suggests an influence of high energy water. The Ammoina beccarii-Elphidium advenum assemblage can be correlated with the Ammonia beccarii-Elphidium advenum assemblage of the upper part of Shanghai Formation in the Shanghai region (Wang and Min, 1979). It is also comparable with the Ammonia beccarii-Elphidium advenum assemblage of the middle part of the Beijian Formation in the Pearl River Mouth Basin (Yang and Lin, 1996).

The foraminifers observed at the upper part of Core ZKA4 do not indicate a direct influence of sea water in this area. The other two cores, however, suggest that their vicinities were under continued influence of marine environment. The upper parts of LZK1 and CSJA6 have a relatively low benthic foraminiferal abundance and diversity, dominated by Ammoina beccarii var. and Elphidium magellanicum. The assemblage also includes Ammonia compressiuscula, Ammonia ketienziensis angulata, Ammonia pauciloculata, Cribrononion subincertum and Elphidium advenum. The Ammonia beccaril-Elphidium magellanicum assemblage may be correlated to the Ammoina keitienziensis-Astrononion tasmensis assemblage and Elphidium magellanicum assemblage of the upper part of Bed H I -1 in South Yellow Sea Shelf (Yang, 1985, 1993; Yang and Lin, 1996) based on the common presence of Ammonia beccarii, Elphidium magellanicum, and Ammonia ketienziensis angulata in each fauna.

AMS ${ }^{14} \mathrm{C}$ dating suggests that the studied sediments of the three cores accumulated during the post-glacial period. The three benthic foraminiferal assemblages can be correlated with the faunas of this region in previous work 


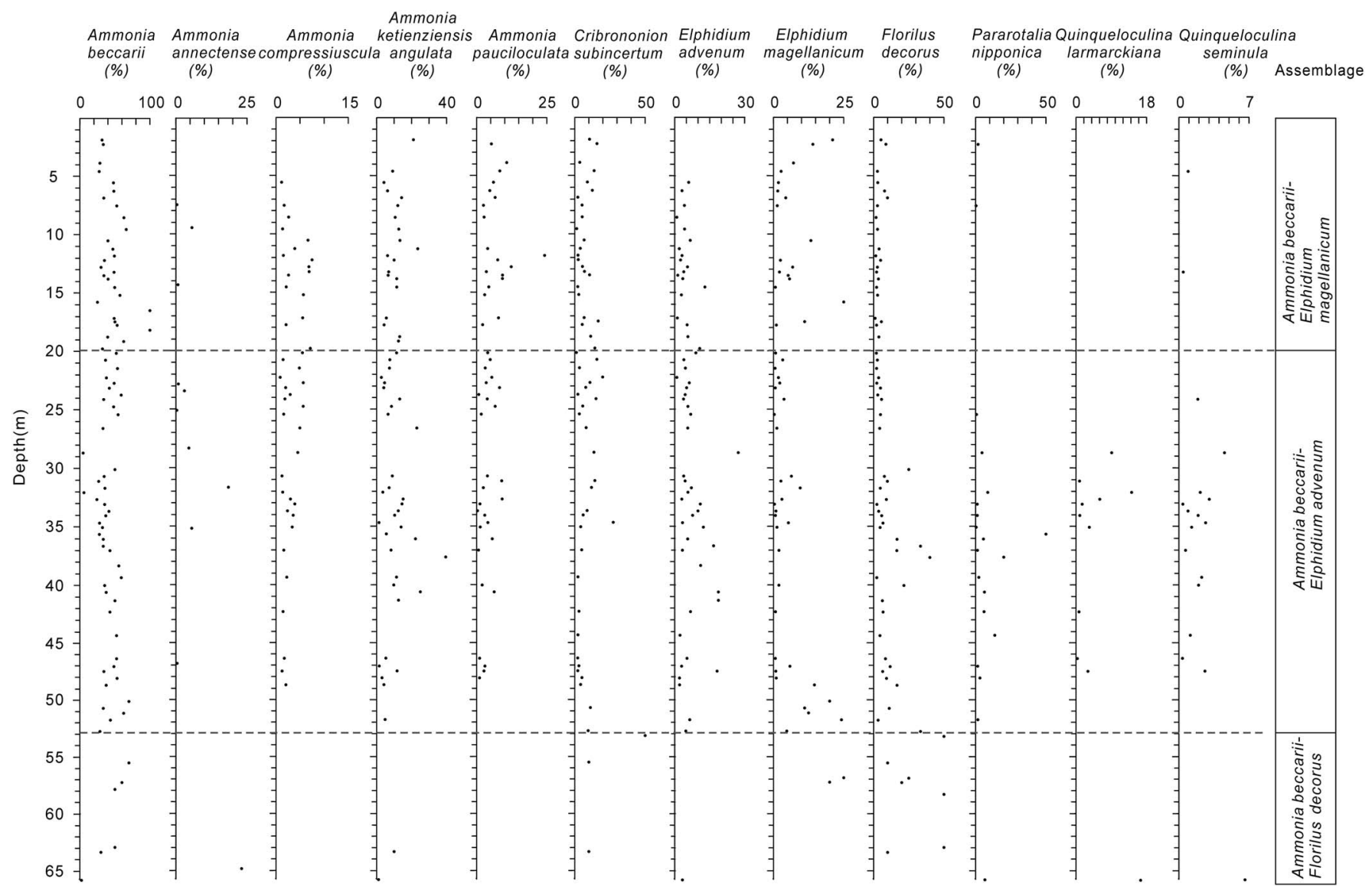

Figure 12. Down-core variations of main species and assemblages of benthic foraminifers in Core CSJA6.

(Min and Wang, 1979), which documented the post-glacial transgresstion-regression history, referred to as the "Ammonia transgression" during the Holocene (Wang et al., 1981).

The Ammonia beccarii-Florilus decorus assemblage points to a weak marine transgression during the early post-glacial period. The Ammoina beccarii-Elphidium advenum assemblage, however, suggests the strongest transgression during the early-middle Holocene, when the warm and relatively deep sea water invaded this region. The Ammoina beccarii-Elphidium magellanicum assemblage corresponds to the late Holocene marine regression, an episode of global sea level drop. Due to the difference in the locations of the studied cores, the results suggest that Core ZKA4 is first out of the influence of the marine water during the late middle Holocene, when the other two cores were still of marine environment during the late Holocene.

\section{Conclusions}

The occurrence of abundant foraminifers in three cores drilled in the incised Yangtze paleo-valley revealed post-glacial environmental changes. Three benthic foraminiferal assemblages are present, including the Ammonia beccari-Florilus decorus assemblage during the early post-glacial period, the Ammoina beccarii-Elphidium advenum assemblage during the early-middle Holocene, and the Ammoina beccarii-Elphidium magellanicum assemblage in the late Holocene. The assemblages can be correlated with the "Ammonia marine transgression" during the Holocene (Wang et al., 1981). The early-middle Holocene benthic foraminiferal assemblage also implies a warm environment because of the occurrence of abundant Cavarotalia annectens and Pararotalia nipponica, and porcellaneous forms. The difference in foraminiferal abundance and diversity suggests that the cores in the modern coastal area are influenced by ocean water since the early post-glacial period, while the upstream core witnessed the transgression only during the middle Holocene. With the global sea level drop, the ocean water retreated from the west since the late middle Holocene and gradually formed the estuary environment in the Yangtze Delta.

\section{Acknowledgments}

We thank Dr. S. Stukins for arranging the observation on the foraminiferal collections at the Natural History Museum (London). We also thank two anonymous reviewers for their detailed and constructive reviews, which considerably improved the manuscript. This study was supported by the NSFC (Grant No. 41276044), CAS Strategic Priority Project (Grant No. XDPB05), and the Foundation of Geological Survey of China (Nos. GZH201200506, 1212011120173, and 121201004000150021).

\section{References}

Andersen, H.V., 1952, Buccella, a new genus of the rotailed Foraminifera: Journal of the Washington Academy of Sciences, v. 42, p. 143-151.

Asano, K., 1950-1953, in Stach, L.W., compl. \& ed., Illustrated Catalogue of Japanese Tertiary Smaller Foraminifera, Parts 1-15, Suppl. 1: Tokyo, Kurogane Printing Co. \& Hosokawa Printing Co., 183 p. 
Banner, F.D., and Culver, S.J., 1978, Quaternary Haynesina n. gen. and Paleogene Protelphidium Haynes; their morphology, affinities and distribution: Journal of Foraminiferal Research, v. 8, p. 177-207.

Barker, R.W., 1960, Taxonomic notes on the species figured by H.B. Brady in his report on the Foraminifera dredged by H.M.S. Challenger during the years 1873-1876. Accompanied by a reproduction of Brady's plates: Special Publications, Society of Economic Paleontologists and Mineralogists, no. 9, 238 p.

Brady, H.B., 1881, Notes of some of the Reticularian Rhizopoda od the "Challenger" Expedition. III: Quarterly Journal of Microscopical Science, n.s., v. 21 , no. 81 , p. $31-71$.

Brady, H.B., 1884, Report on the foraminifera dredged by H.M.S. Challenger during the years 1873-1876: Report of the Scientific Results of the Voyage of H.M.S Challenger During the Years 1873-76, Zoology, v. 9, p. 1-814.

Brünnich, M.T., 1772, M.T. Brünnich Zoologiae fundamenta. Grunde I Dyrelaeren: Hafniae et Lipsiae, Apud Frider. Christ. Pelt., 254 p.

Bykova, N.K., 1959, K voprosu o zakonomernostyakh filogeneticheskogo razvitiya foraminifer $\mathrm{v}$ usloviyakh periodicheski izmenyayushcheysya sredy (On the question of conformity in phylogenetic development of the foraminifera under conditions of a recurrent variable environment): Voprosy Paleobilogii i Biostratigrafii, Trudy-Sessii Vsesoyuznogo Paleontologicheskogo Obshchestva, Moscow, p. 63-75. [in Russian]

Chen, Z.Y., and Stanley, D.J., 1995, Quaternary subsidence and river channel migration in the Yangtze Delta Plain, Eastern China: Journal of Coastal Research, v. 11, p. 927-945.

Cheng, T.C., and Zheng, S.Y., 1978, The recent foraminifera of the Xisha Islands, Guangdong Province, China (I): Studia Marina Sinica, v. 12, p. 149-266. [in Chinese with part in English]

Cushman, J.A., 1913, A monograph of the Foraminifera of the North Pacific Ocean: United States National Museum Bulletin, v. 71, pt. 3, 110 p.

Cushman, J.A., 1915, A monograph of the Foraminifera of the North Pacific Ocean: United States National Museum Bulletin, v. 71, pt. 5, 75 p.

Cushman, J.A., 1917, A monograph of the Foraminifera of the North Pacific Ocean: United States National Museum Bulletin, v. 71, pt. 6, p. 1-98.

Cushman, J.A., 1922a, Shallow-Water Foraminifera of the Tortugas Region: Carnegie Institution of Washington Publication, no. 311, v. 17, p. 1-75.

Cushman, J.A., 1922b, The Foraminifera of the Atlantic Ocean: United States Notional Museum Bulletin, v. 104, pt. 2, 137 p.

Cushman, J.A., 1922c, Results of the Hudson Bay expedition, 1920, I-The foraminifera: Contributions to Canadian Biology, 1921, Biological Board of Canada, no. 9, p. 135-147

Cushman, J.A., 1923, The Foraminifera of the Atlantic Ocean: United States National Museum Bulletin, v. 104, pt. 4, 178 p.

Cushman, J.A., 1926, Foraminifera of the typical Monterey of California: Contributions from the Cushman Laboratory for Foraminiferal Research, v. 2 , p. $53-69$

Cushman, J.A., 1927, An outline of a re-classification of the foraminifera: Contributions from the Cushman Laboratory for Foraminiferal Research, no. 3, 1-105.

Cushman, J.A., 1929, The Foraminifera of the Atlantic Ocean: United States National Museum Bulletin, v. 104, pt. 6, 100 p.

Cushman, J.A., 1931, The Foraminifera of the Atlantic Ocean: United States National Museum Bulletin, v. 104, pt. 8, 144 p.

Cushman, J.A., 1933, Some new recent foraminifera from the tropical Pacific: Contributions from the Cushman Laboratory for Foraminiferal Research, v. 9 , p. $1-21$.

Cushman, J.A., 1936a, Some new species of Elphidium and related genera: Contributions from the Cushman Laboratory for Foraminiferal Research, v. 12, p. $78-89$.

Cushman, J.A., 1936b, New genera and species of the families Vemeuillinidae and Valvulinidae and of the subfamily Virgulininae: Contributions from the Cushman Laboratory for Foraminifera Research Special Publication, v. 12, p. 83-84.

Cushman, J.A., 1939, A monograph of the foraminiferal family Nonionidae: United States Geological Survey Professional Paper, v. 191, p. 1-100.

Cushman, J.A., and McCulloch, I., 1950, Some Lagenidae in the collections of the Allan Hancock foundation: Allan Hancock Pacific Expeditions, v. 6, p. $295-364$.

Cushman, J.A., and Ozawa, Y., 1930, A Monograph of the foraminiferal family Polymorphinidae recent and fossil: Proceedings of the United States National Museum, v. 77, pt. 6, p. 1-185.

Cushman, J.A., and Todd, R., 1944, The genus Spiroculina and its species: Cushman Laboratory of Foraminiferal Research Special Publication, no. 11, 82 p.

de Montfort, P.D., 1808, Conchyliologie Systématique et Classification Méthodique des Coquilles: Paris, F. Schoell, 410 p.

d'Orbigny, A., 1826, Tableau méthodique de la classe des Céphalopodes: Annales des sciences naturelles, ser. 1, v. 7, p. 245-314.

d'Orbigny, A., 1839a, Foraminifères, in de la Sagra, R., Histoire physique, politique et naturelle de l'íle de Cuba: Paris, Arthus Bertrand, v. 6, 224 p.
d'Orbigny, A., 1839b, Voyage dans l'Amérique mérigionate-Foraminifères, v. 5, pt. 5: Paris and Strasbourg, P. Bertrand, 86 p.

d'Orbigny, A., 1846, Foraminifères fossiles du Bassin Tertiaire de Vienne: Paris, Gide et Comp, $312 \mathrm{p}$

Delage, Y., and Hérouard, E., 1896, Truité de Zoologie Concrète, v. 1, La Cellule et les Protozoaires: Paris, Schleicher Frères, p. 120-124.

Ehrenberg, C.G., 1838, Über dem blossen Auge unsichtbare Kalkthierchen und Kieselthierchen als Hauptbestandtheile der Kreidegebirge: Bericht über die zu Bekanntmachung geeigneten Verhandlungen der Königlichen Preussischen Akademie der Wissenschaften zu Berlin, v. 1838, p. 192-200.

Ehrenberg, C.G., 1839, Über die Bildung der kreidefelsen und des Kreidemergels durch unsichtbare Organismen: Physikalische Abhandlungen der Königlichen Akademie der Wissenschaften zu Berlin, 1838 (1840: separate 1839), p. 59-147.

Eichwald, C.E., von, 1830, Zoologia Specialis, v. 2: Vilnae, D.E. Eichwaldus, $323 \mathrm{p}$.

Fleming, K., Johnston, P., Zwartz, D., Yokoyama, Y., Lambeck, K., and Chappell, J., 1998, Refining the eustatic sea-level curve since the Last Glacial Maximum using far- and intermediate-field sites: Earth and Planetary Science Letters, v. 163, p. 327-342.

Galloway, J.J., 1933, A Manual of Foraminifera: Bloomington, Indiana, Principia Press, $483 \mathrm{p}$

Gennari, G., Rosenberg, T., Spezzaferri, S., Berger, J.P., Fleitmann, D. Preusser, F., Al-Shanti, M., and Matter, A., 2011, Faunal evidence of a Holocene pluvial phase in Southern Arabia with remarks on the morphological variability of Helenina Anderseni: Journal of Foraminiferal Research, v. 41, p. $248-259$.

Griffith, J.W., and Henfrey, A., 1875, The Micrographic Dictionary, v. 1: London, van Voorst, $845 \mathrm{p}$.

Guo, Q.M., Li, B.H., Wang, W.M., Lan, X., and Ding, J.L., 2014, Age and paleoenvironment of the Oyster Layer in the Bailian Lake, Jiangsu Province: Acta Micropalaeontologica Sinica, v. 31, p. 147-153. [in Chinese with English abstract]

Guo, Y.G., Li, Y.C., Xu, D.Y., Li, X.Q., and Zhang, X.H., 1997, Tectonic evolution of Yellow Sea and East China Sea continental shelf and adjacent areas: Marine Geology and Quaternary Geology, v. 17, p. 1-11. [in Chinese with English abstract]

Haynes, J.R., 1956, Certain smaller British Paleocene foraminifera, Part 1. Nonionidae, Chilostomellidae, Epistominidae, Discorbidae, Amphisteginidae, Globigerinidae, Globorotaliidae and Gümbelinidae: Contributions of the Cushman Foundation for Foraminiferal Research, v. 7, p. 79-101.

He, Y., Hu, L.Y., and Wang, K.L., 1965, The Quaternary foraminifera of the east Jiangsu Province, China: Memoir of Institute of Geology and Palaeontology, Academia Sinica, v. no. 4, p. 51-162. [in Chinese and Russian]

Heron-Allen, E., and Earland, A., 1932, Foraminifera Part 1: the ice-free area of the Falkland Islands and adjacent seas: Discovery Report, v. 4, p. 291-460.

Ishizaki, K., 1940, On Streblus schroeterianus (Parker et Jones) and allied species: Taiwan Tigaku Kizi, v. 11, p. 49-61.

Jones, R.W., 1994, The Challenger Foraminifera: Oxford, New York, Tokyo, Oxford University Press, $149 \mathrm{p}$

Karrer, E., 1868, Die Miocene Foraminiferen-fauna von Kostej im Banat: Sitzungsberichte der Kaiserlichen Akademie der Wissenschaften Wien, Mathematisch-Naturwissenschaftliche Klasse, v. 58, p. 121-193.

Lankester, E.R., 1885, Protozoa, in Encyclopaedia Britannica, 9th ed., Philadelphia, J. M. Stoddard Co., Ltd., v, 19, p. 830-866.

Li, B.H., Wang, X.Y., Kong, X.M., Lin, C.M., Li, Y.L., and Zhang, X., 2012, Post-glacial foraminiferal record of the Southern Qiantang River Estuary and its paleoenvironmental implications: Acta Micropalaeontologica Sinica, v. 29, p. 121-129. [in Chinese with English abstract]

Li, C.X., and Wang, P.X, 1998, Stratigraphy in the Estuary of Yangtze Delta During the Late Quaternary: Beijing, Science Press, 222 p. [in Chinese]

Li, C.X., Chen, Q.Q., Zhang, J.Q., Yang, S.Y., and Fan, D.D., 2000, Stratigraphy and palaeoenvironmental changes in the Yangtze Delta during the late Quaternary: Journal of Asian Earth Sciences, v. 18, p. 453-459.

Li, C.X., Wang, P.X., Sun, H., Zhang, J.Q., and Fan, D.D., 2002, Late Quaternary incised-valley fill of the Yangtze delta (China): its stratigraphic framework and evolution: Sedimentary Geology, v. 152, p. 133-158.

Li, G.Z., Bian, Y.H., and Wang, P.X., 1988, Holocene marine transgression and its micropaleontological characteristics in the north-eastern waters of Beibu Gulf: Tropic Oceanology, v. 2, p. 63-70. [in Chinese with English abstract]

Lin, J., 1979, The Quaternary foraminifera in Eastern Hebei: Journal of the Institute of Geology, v. 1, p. 61-85. [in Chinese with English abstract]

Loeblich, A.R., and Tappen, H., 1961, Suprageneric classification of the Rhizopodea: Journal of Paleontology, v. 35, p. 245-330.

Loeblich, A.R., and Tappen, H., 1988, Foraminiferal Genera and Their Classification: New York, Van Nostrand Reinhold Company, $970 \mathrm{p}$.

Ma, X., Yu, J.J., Jiang, R., Zhang, Z.Y., Lao, J.X., Zhao, L., and Wei, N.Y., 2015, Grain-size analysis of the Quaternary sediments in Borehole ZKA4 in 
the Yangtze River Delta and its paleoenvironment and paleoclimate implications: Journal of Stratigraphy, v. 39, p. 423-432. [in Chinese with English abstract]

Min, Q.B., and Wang, P.X., 1979, Quaternary transgressions in Shanghai region: Journal of Tongji University, p. 109-128. [in Chinese with English abstract]

Müller-Merz, E., 1980, Strukturanalyse ausgewählter rotaloider Foraminiferen (Structural analysis of selected rotaliid Foraminifera): Schweizerische Paläontologische Abhandlungen, v. 101, p. 5-70.

Murray, J.W., 1971, An Atlas of British Recent Foraminiferids: London, Heinemann Educational Books, 244 p.

Parker, W.K., and Jones, T.R., 1865, On some foraminifera from the North Atlantic and Arctic Ocean, including Davis Straits and Baffin's Bay: Philosophical Transactions of the Royal Society of London, v. 155, p. 325-442.

Phleger, F.B., and Parker, F.L., 1951, Ecology of Foraminifera Northwest Gulf of Mexico, Part 2: Foraminifera Species: Geological Society of America, Memoir, v. 46, p. 1-64.

Reuss, A.E., 1850, Neue Foraminiferen aus den Schichten des österreichischen Tertiärbeckens: Denkschriften der Kaiserlichen Akademie der Wissenschafter, v. 1, p. 365-390.

Reuss, A.E., 1858, Ueber die Foraminiferen von Pietzpuhl: Zeitschrift der Deutschen Geologischen Gesellschaft, v. 10, p. 433-439.

Reuss, A.E., 1863, Beiträge zur Kenntniss der tertiären Foraminiferen-Fauna (Zweite Folge), Sitzungsberichte der Kaiserlichen Akademie der Wissenschaften in Wien: Mathematisch-Naturwissenschaftliche Classe, v. 48, p. 36-71.

Roemer, F.A., 1838, Cephalopoden des Nord-Deutschen tertiären Meersandes: Neues Jahrbuch für Mineralogie, Geognosie, Geologie und PetrefaktenKunde, p. 381-394.

Saunders, J.B., 1957, Emendation of the foraminiferal genus Palmerinella Bermudez, 1934, and erection of the foraminiferal genus Helena: Journal of the Washington Academy of Sciences, v. 47, p. 374.

Saunders, J.B., 1961, Helenina Saunders, new name for the foraminiferal genus Helenia Saunders, 1957, non Helenia Walcott, 1880: Contributions from the Cushman Foundation for Foraminiferal Research, v. 12, p. 148.

Schultze, M.S., 1854, Über den Organismus der Polythalamien (Foraminiferen), nebst Bermerkungen über die Rhizopoden im Allgemeinen: Leipzig, Wilhelm Engelmann, 68 p.

Seguenza, G., 1862, Die Terreni Terziarii del Distretto di Messina. Parte IIDescrizione dei Foraminiferi Monotalamici delle Marne Mioceniche del Distretto di Messina: Messina, Capra, $84 \mathrm{p}$

Shannon, C.E., 1948, A mathematical theory of communication: The Bell System Technical Journal, v. 27, p. 379-423, 623-656

Shu, Q., Xiao, J.Y., Zhao, Z.J., Zhang, M.H., Cheng, Y., and Li, J.J., 2010, Environmental records in $\mathrm{XH}-1$ core in northern Jiangsu Basin since about 780 Ka B.P.: Journal of Stratigraphy, v. 1, p. 27-34. [in Chinese with English abstract]

Stanley, D.J., and Chen, Z.Y., 1996, Neolithic settlement distributions as a function of sea level-controlled topography in the Yangtze delta, China: Geology, v. 24, p. 1083-1086.

Stanley, D.J., and Chen, Z.Y., 2000, Radiocarbon dates in China's Holocene Yangtze delta: record of sediment storage and reworking, not timing of deposition: Journal of Coastal Research, v. 16, p. 1126-1132.

Thalmann, H.E., 1947, Mitteilungen über Foraminiferen V: Eclogae Geologicae Helvetiae (1946), v. 39, p. 309-314.

Todd, R., and Bronnimann, P., 1957, Recent foraminifera and theamoebina from the eastern gulf of Paria: Cushman Foundation for Foraminiferal Research Special Publication, v. 3, p. 1-43.

Ujiié, H, 1990, Bathyal benthic foraminifera in a Piston Core from East of the Miyako Islands, Ryukyu Island Arc: Bulletin of the College of Science, University of the Ryukyus, v. 49, p. 1-60.

Walker, G., and Jacob, E., 1798, An arrangement and description of minute and rare shells, in Essay on the Microscope, by the late George Adams, the Second Edition, with considerable additions and improvements, by Frederick Kanmacher, F.L.S.: London, Dillon and Keating, p. 629-664.

Wang, P.X., 1980, Papers on Marine Micropaleontology: Beijing, China Ocean Press, 191 p. [in Chinese]

Wang, P.X., and Gu, S.Y., 1980, Quaternary transgressions in the Lower Liao River plain, Liaoning province, in Wang, P.X., ed., Papers on Marine Micropaleontology: Beijing, China Ocean Press, p. 130-139. [in Chinese with English abstract]
Wang, P.X., and Min, Q.B., 1979, Quaternary transgression in Shanghai region: Journal of Tongji University, v. 2, p. 109-128. [in Chinese]

Wang, P.X., Min, Q.B., and Bian, Y.H., 1980a, Distribution of Foraminifera and Ostracoda in bottom sediments of the Northwestern part of the Southern Yellow Sea and its geological significance, in Wang, P.X., ed., Papers on Marine Micropaleontology: Beijing, China Ocean Press, p. 61-83. [in Chinese with English contents]

Wang, P.X., Min, Q.B., and Gao, J.X., 1980b, A preliminary study of foraminiferal and ostracod assemblages of the Yellow Sea, in Wang, P.X., ed., Papers on Marine Micropaleontology: Beijing, China Ocean Press, p. 84-100. [in Chinese with English abstract]

Wang, P.X., Min, Q.B., Bian, Y.H., and Chen, X.R., 1981, Strata of Quaternary transgressions in East China: ACTA Geologica Sinica, v. 1, p. 1-13. [in Chinese with English abstract]

Wang, P.X., Zhang, J.J., Zhao, Q.H., Min, Q.B., Bian, Y.H., Zheng, L.F., Cheng, X.R., and Chen, R.H., 1988, Foraminifera and Ostracoda in Bottom Sediments of the East China Sea: Beijing, China Ocean Press, 438 p. [in Chinese with English abstract]

Wang, S.H., Yu, M.T., Tang, Y.L., Zhao, X.T., Wang, X.M., and Huang, X.H., 2002, Holocene foraminifera and it's environmental significance in Shenhu Bay, Fujian: Journal of Oceanography in Taiwan Strait, v. 21, p. 6-11. [in Chinese with English abstract]

Wang, Z.H., Zhang, D., Li, X., Tao, S.K., and Xie, Y., 2008, Magnetic properties and relevant minerals of late Cenozoic sediments in the Yangtze River delta and their implication: Geology in China, v. 35, p. 670-682. [in Chinese with English abstract]

Wang, Z.H., Zhuang, C.C., Saito, Y., Chen, J., Zhan, Q., and Wang, X.D., 2012, Early mid-Holocene sea-level change and coastal environmental response on the southern Yangtze delta plain, China: implications for the rise of Neolithic culture: Quaternary Science Reviews, v. 35, p. 51-62.

Wang, Z.H., Zhan, Q., Long, H.Y., Saito, Y., Gao, X., Wu, X.X., Li, L., and Zhao, Y.N., 2013, Early to mid-Holocene rapid sea-level rise and coastal response on the southern Yangtze delta plain, China: Journal of Quaternary Science, v. 28, p. 659-672.

Warren, A.D., 1957, Foraminifera of the Buras-Scofield Bayou region, southeast Lousiana: Contributions of the Cushman Foundation for Foraminiferal Research, v. 8, p. 29-40.

Williamson, W.C., 1858, On the Recent Foraminifera of Great Britain: London, Printed for the Ray Society, $100 \mathrm{p}$.

Wu, B.Y., and Li, C.X., 1987, Quaternary Geology of Yangtze Delta: Beijing, China Ocean Press, 170 p. [in Chinese]

Xiong, Z., Hou, K.M., Li, Q.H., and Chen, J., 2010, Standard well for Quaternary research and its geological interpretation in Qinhuai River Valley of Nanjing area: Geological Journal of China Universities, v. 4, p. 498-508. [in Chinese with English abstract]

Yang, Z.G., 1985, Sedimentology and environment in South Yellow Sea Shelf since Late Pleistocene: Marine Geology \& Quaternary Geology, v. 5, no. 4, p. 1-19. [in Chinese with English abstract]

Yang, Z.G., 1993, The sedimentary sequence and Palaeogeographic changes of the South Yellow Sea since the Olduval Subchron: ACTA Geologica Sinica, v. 67, p. 357-366. [in Chinese with English abstract]

Yang, Z.G., and Lin, H.M., 1996, Quaternary stratigraphy in China and its international correlation: Beijing, Geological Publishing House, p. 31-107. [in Chinese with English contents]

Yu, J.J., Hu, F., Yang, Z.L., Zhang, Z.Y., Jiang, R., Ke, X., and Lao, J.X., 2014, Identification of Holocene foraminifera assemblages in Sijia Town of Nantong City, Jiangsu Province, and its geological significance: Geological Bulletin of China, v. 33, p. 1609-1620. [in Chinese with English abstract]

Zheng, S.Y., Cheng, T.C., Wang, X.T., and Fu, Z.X., 1978, The Quaternary foraminifera of the Dayuzhang irrigation area, Shangdong Province, and a preliminary attempt at an interpretation of its depositional environment Studia Marina Sinica, v. 13, p. 16-78. [in Chinese and part of English]

Zhu, X.H., and Lin, M.H., 1990, Fossil fauna and transgression sequence of the Core QC2 in South Yellow Sea: ACTA Oceanologica Sinica, v. 9, p. 561-578. [in Chinese with English abstract]

Accepted 14 June 2017 